NBER WORKING PAPER SERIES

\title{
BANK MERGERS, ACQUIRER CHOICE AND SMALL BUSINESS LENDING: IMPLICATIONS FOR COMMUNITY INVESTMENT
}

\author{
Bernadette A. Minton \\ Alvaro G. Taboada \\ Rohan Williamson \\ Working Paper 29284 \\ http://www.nber.org/papers/w29284 \\ NATIONAL BUREAU OF ECONOMIC RESEARCH \\ 1050 Massachusetts Avenue \\ Cambridge, MA 02138 \\ September 2021
}

We thank Hamid Mehran, Philip Strahan and René M. Stulz for helpful comments and suggestions as well as seminar participants at Georgetown University, Babson College, University of Wisconsin-Milwaukee, Federal Reserve Board, The Ohio State University, 2019 Financial Management Associations Meeting, and Villanova University's WiFi Seminar Series. Rohan Williamson is chair of the board of a bank. The views expressed herein are those of the authors and do not necessarily reflect the views of the National Bureau of Economic Research.

NBER working papers are circulated for discussion and comment purposes. They have not been peer-reviewed or been subject to the review by the NBER Board of Directors that accompanies official NBER publications.

(C) 2021 by Bernadette A. Minton, Alvaro G. Taboada, and Rohan Williamson. All rights reserved. Short sections of text, not to exceed two paragraphs, may be quoted without explicit permission provided that full credit, including (C) notice, is given to the source. 
Bank Mergers, Acquirer Choice and Small Business Lending: Implications for Community Investment

Bernadette A. Minton, Alvaro G. Taboada, and Rohan Williamson

NBER Working Paper No. 29284

September 2021

JEL No. G21,G34,O1

\section{ABSTRACT}

We examine the effects of bank merger and local market characteristics on local small business lending. Mergers involving small, in-state acquirers are positively associated with small business loan (SBL) originations in counties where target banks are located. Conversely, mergers involving large, out-of-state acquirers are associated with fewer SBL originations. The analysis suggests that the results are driven by acquirer's choice of target. Small and in-state acquirers target banks that focus more on SBL and targets with strong relationships while large, out-of-state acquirers pursue better performing banks with stronger balance sheets and less focus on SBL. Results are particularly strong in counties with a large number of small firms. Post-merger activity supports banks expanding on their acquisition strategy decisions. The findings suggest that acquirer strategy is important for evaluating the impact of acquisitions on local community development and that one-size-fits-all policy solutions for bank mergers may not produce common local outcomes.

Bernadette A. Minton

Finance Department

Fisher College of Business

700 Fisher Hall

2100 Neil Avenue

Columbus, OH 43210-1144

minton.15@fisher.osu.edu
Rohan Williamson

McDonough School of Business

Georgetown University

587 Hariri Building

Washington, DC 20057

and NBER

rohan.williamson@georgetown.edu

Alvaro G. Taboada

Mississippi State University

P.O. Box 9580

Mississippi State, MS 39762

ataboada@business.msstate.edu

A data appendix is available at http://www.nber.org/data-appendix/w29284 


\section{Introduction}

Small businesses play a vital role in community investment and economic development through job creation and through the provision of goods and services for local consumption and rely on relationships with local banks to finance investment (See, for example, Berger and Udell, 1995; Stein, 2002, and Levine, Lin, Peng, and Xie, 2020). This paper examines the differential effects of bank mergers, including acquirer's target choice, and local market characteristics on community investment through small business loan originations. During our sample period, there was a substantial decrease in the number of FDIC-insured commercial banks from about 8,600 in 1999 to just over 4,500 as of 2019. This decline was driven by an active merger market with over $90 \%$ of the mergers involving target banks with under $\$ 10$ billion in assets (i.e., small and community banks), coupled with fewer de novo banks since the financial crisis (Strahan, 2017). The recent press response to the COVID-19 pandemic highlights the importance of small banks for community investment. As noted in the press, banks with assets below $\$ 10$ billion were responsible for $60 \%$ of loans in the first phase of the Payroll Protection Program (PPP) through the CARES Act. One small bank CEO commented, "Our bank personnel is so connected to those clients that it went bing, bing, bing." " Thus, the disappearance of small banks from certain geographical markets due to acquisitions by large banks may negatively affect community investment through reductions in small business loan (SBL) originations in those markets.

The majority of small business lending, especially the smallest of such loans (those with amounts below $\$ 100,000$, which account for about $93 \%$ of the total number of SBL originations during our sample period), are to businesses that are less likely to have detailed audited financial statements. Thus, loans to such borrowers are based, in part, on soft information that is acquired over time and is not easily transmitted to others (Stein, 2002; Levine et al., 2020) suggesting that the ability to process soft information is important for community investment. Prior research shows that large and distant banks are more likely to depend on hard technology driven information (see, e.g. Petersen and Rajan, 2002). In contrast, small banks tend to specialize more in soft information-based lending where they have a competitive advantage relative to large banks

\footnotetext{
${ }^{1}$ Small Banks Grabbed Lead in Rescue Effort, Wall Street Journal, Peter Rudegeair, Orla MCaffrey and Liz Hoffman, May 4, 2020.
} 
(Liberti and Petersen, 2019; Berger and Black, 2011; Berger and Udell, 1995, 2002; Berger, et al., 2005; Cole, Goldberg, and White, 2004, and Berger, Bouwman and Kim, 2017). The literature also shows that relative to smaller banks, large banks tend to invest less in small business loans as a percentage of their total assets (See, for example, Berger et al., 1998; Cole, Goldberg, and White, 2004, and Keeton, 1995). Therefore, the reduction in small banks could have important implications for small business investment driven by acquirer characteristics and strategy.

To examine the effect of bank mergers and local market characteristics on small business lending we use data on SBL originations from the Federal Financial Institutions Examination Council's (FFIEC) Community Reinvestment Act (CRA) database. Ceteris paribus, a decline in the number (or plausible disappearance) of small banks with a comparative advantage in soft information processing from a market after mergers would lead to a reduction in local lending. The potential reduction in small business lending could be mitigated by the acquirer's strategy. Some acquirers with a competitive advantage in small business lending may pursue strategies to increase their share in SBL originations, leading to an increase in small business lending. On the other hand, mergers could lead to a reduction in small business lending when acquirers are less focused on further developing local SBL originations. Prior literature shows that small banks tend to have an advantage in small business lending, which would predict that small acquirers would be more likely to increase local small business lending relative to large acquirers. Our results are in line with these predictions. We show that mergers involving small acquirers are associated with increases in SBL originations in the target's county, especially for small SBL originations. In contrast, mergers involving large acquirers are associated with decreases in small SBL originations.

In addition to size, acquirer location is likely to affect the impact of mergers on small business lending given the information advantage of local acquirers relative to distant acquirers. Acquirers that are closer or more familiar with the target's market may find it easier to obtain soft information required to be profitable at making local small business loans. ${ }^{2}$ This suggests that mergers with out-of-state or more distant acquirers may

\footnotetext{
${ }^{2}$ For example, Agarwal and Hauswald (2010) find that private information production is facilitated by proximity to the borrower, while DeYoung, Glennon, and Nigro (2008) show that distance between banks and their borrowers are associated with higher defaults, consistent with the view that distance hinders banks' ability to collect private information.
} 
lead to a reduction in target county SBLs post-merger. Our results show that mergers involving in-state acquirers are associated with increases in SBL originations in the target's county, while mergers involving outof-state acquirers have no effect on SBL originations.

The local outcomes on community investment driven by acquirer characteristics could be explained by differences in the types of target banks; large and out-of-state banks could focus on targets with different characteristics than those targeted by small and local banks because of differences in their strategic objectives. Large and out-of-state banks that lack an understanding of the targets' local markets could pursue targets that are more profitable, with stronger balance sheets that are less risky and are less focused on SBL originations. In contrast, local small banks with an interest in expanding their share of small business lending, where they have a comparative advantage relative to large or out-of-state acquirers, may target banks with more of a focus on small business lending.

The results support this idea. We find that small local acquirers tend to focus on targets that are more focused on SBL originations, while large acquirers focus on targets with strong balance sheets and low concentration in small business lending. This result reinforces the aforementioned findings that large acquirers tend to reduce local SBL originations while small and local acquirers use the acquisitions to increase lending in the target county. Because local small local banks target banks that are more constrained in lending, the acquisition allows the acquirer to increase local lending, which is their focus, while large banks are more interested in stronger and more stable banks to expand the franchise and not focus on local SBL originations.

The composition of firms in the target bank's market also could be an important consideration for the impact of mergers on small business lending. ${ }^{3}$ For instance, one may expect the effect of mergers on small business lending to differ based on the proportion of small opaque firms in the local target bank's market since these firms require the use of more soft information in loan evaluation, where small local banks have an advantage. Consistent with this view, we find that the positive impact of mergers involving small and in-state acquirers on small SBL originations is concentrated in counties with a large fraction of small firms with fewer

\footnotetext{
${ }^{3}$ The size of the borrowing firms may affect the extent to which the hard (soft) Information advantage dominates (see e.g. Berger and Black, 2011).
} 
than 50 employees (i.e., opaque counties). We do not find a differential effect for mergers involving large or out-of-state acquirers in opaque counties. These results underscore the importance of banks' differential lending strategies in small business lending and support the view that small local acquiring banks tend to focus more on SBL originations.

We further examine the impact of local mergers on community investment by analyzing SBL originations by the acquiring bank and other local banks in the counties where the target has the largest presence using a difference-in-difference (DiD) design focusing on a six-year window around the merger. Consistent with the county-level results, we find significant increases in SBL originations by small acquirers post-merger relative to the control group, especially for in-state mergers and those in opaque counties. In contrast, we find no significant change in SBL originations post-merger for large acquirers. When we examine small business lending by competitor banks in the target counties, we find a decrease in SBL originations postmerger for mergers involving small and large acquirers. These results suggest that the positive effects of mergers by small acquirers on SBL originations in the target's county are likely driven by the increased lending activity of such acquirers, driven in part, by their increased market power. In contrast, the adverse effects on small SBL originations for mergers involving large acquirers at the county level may be partially explained by the competitor banks' response to such mergers.

A concern with our analyses is that any documented relation between merger activity and community investment may not be causal, given inherent endogeneity issues. For instance, high demand for small business loans in a county may make banks operating in the county attractive targets for acquisitions, especially if acquirers are interested in growing their SBL portfolio. Alternatively, banks in declining markets may be more attractive takeover targets. The observed subsequent changes in SBL originations, thus, may be a result of omitted (e.g. demand-side) county level factors that affect both SBL originations as well as merger activity involving targets with a presence in the county. To address this concern we employ an instrumental variable (IV) strategy similar to the one used in prior studies assessing how banks' geographic diversification affects bank risk and cost of funds (Goetz, Laeven, and Levine, 2016; Levine, Lin, and Xie, 2021, and Faia, Laffitte, and Ottaviano, 2019). Specifically, we instrument our merger intensity using the predicted level of merger 
activity from a gravity equation, akin to the approach used by Frankel and Romer (1999) to examine the effects of international trade flows. Results using the IV approach corroborate our main findings.

Overall, our results highlight the importance of examining acquirer strategy and local county characteristics when evaluating the impact of bank mergers on local community investment. Small acquirers, both local and out-of-state, increase SBL originations following mergers while large acquirers do not. This is consistent with the notion that small and local acquirers are uniquely important for local community investment relative to large acquirers because of their advantage in processing soft information, particularly in counties with a large number of small firms.

The paper contributes to the literature on bank behavior with important policy implications. Using a more comprehensive sample of bank mergers than earlier papers, we extend earlier work on bank mergers and small business lending (See Berger et al., 1998; Peek and Rosengren, 1998; Jagtiani, Kotliar, and Maingi, 2016; Strahan and Weston, 1996, 1998) by examining SBL originations in the local markets of the target banks during an active period of merger activity and by exploring concurrently the impact of various acquirer and county characteristics. Most recent related work focuses on large banks and how lending has changed as a result of the financial crisis (see, e.g. Chen, Hanson, and Stein, 2017; Acharya, Berger, and Roman, 2018); Cortés, Demyanyk, Li, Loutskina, and Strahan, 2020), with little focus on small and local banks and how these banks may affect the local community. Relatedly, Bord, Ivashina, and Taliaferro (2018) examine changes in small business lending by large banks based on their exposure to real estate activity in other parts of the country. Though large banks account for most of the dollar amount of SBLs, small banks account for a large proportion of SBL originations, especially loans to small firms (those with revenues $<\$ 1$ million) and therefore are important for community investment and development. ${ }^{4}$ This paper sheds light on the relative impact of large versus small banks on community investment by providing a more comprehensive picture of the importance of bank consolidation on SBL and community investment than has been done to date. Our findings provide new and important insights on the importance of small bank and local community investment.

\footnotetext{
${ }^{4}$ On average, small banks account for $37.5 \%$ (27.0\%) of total (small) SBL originations, and for $42.3 \%$ of loans to small firms during our sample period.
} 
Importantly, the paper contributes to the literature on potential explanations for the target choices of large distant acquirers relative to small local acquirers driven by bank strategy choices and financial constraints as in Erel, Jang and Weisbach (2015). Acquirer banks have differing goals when making acquisitions that are driven by target and local market characteristics, which help explain the local effects on small business lending and community investment. We show that the acquiring banks build on these strategies following the acquisition for at least three years, which affects lending by other banks in the community.

In addition, our study contributes to the existing literature on the role of bank size and proximity on small business lending by highlighting the importance of local market opacity on the value of soft information technology in lending. This result provides clarity on the mixed evidence on the role of bank size in lending to informationally opaque firms (e.g. Strahan and Weston, 1998; Berger, Goulding, and Rice, 2014; Jayaratne and Wolken, 1999; Berger, Rosen, and Udell, 2007). It also supports the role of distance between borrowers and lenders in the production of private information and small business lending (Agarwal and Hauswald, 2010; DeYoung, et al., 2008; Degryse and Ongena, 2005) and extends recent evidence suggesting that credit markets are still local, especially for small firms by examining small and large bank acquirers in new markets (e.g. Nguyen, 2019; Wang, 2019).

Finally, the results in this paper have important and currently relevant implications for policy makers as they evaluate the importance of small banks. As noted previously, small banks play a role in Congressional actions to encourage or maintain community investment during economic crises as reflected in the 2020 CARES Act through the Payroll Protection Program. Additionally, policy makers are concerned about the impact of the increased bank merger activity on community investment and development because of the importance of small banks and their direct relationships with small firms and communities in providing loans for local investment and overall economic development. This paper shows that there are many factors related to mergers linked to acquirer strategy including acquirer size, acquirer headquarter location, and county characteristics that are important considerations in assessing the impact of bank mergers on community investment. Thus, one-size-fits-all solutions are not likely to lead to common outcomes at the local level. Our results suggest that encouraging mergers by small banks and by in-state acquirers may have a positive impact 
on small business lending and community investment, especially in counties with a large fraction of small firms.

The paper proceeds as follows. Section 2 discusses the data and sample. Mergers and SBL originations at the county levels are examined in Section 3; section 4 presents robustness tests of county level results; section 5 investigates bank level results. Section 6 concludes.

\section{Data and sample description}

To assess the importance of bank merger characteristics on community investment through their impact on small business lending, we compile data from a variety of sources. We collect data on SBL originations by financial institutions from the Disclosure Reports in the FFIEC's CRA database that provide detailed data on loan originations by reporting institutions by county. ${ }^{5}$ We obtain data on lending from the CRA database for 3,054 unique banks. Data on bank mergers from 1999 through 2019 are from the Federal Deposit Insurance Corporation's (FDIC) Report of Changes. We also use data on bank branches and deposits by county from the FDIC's Summary of Deposits (SOD) database. Information on county-level measures of employment, population, and additional business conditions is from the Bureau of Economic Analysis and the Federal Housing Finance Agency. Finally, financial data are from the quarterly Call Reports from March 1999 through December 2019; we follow Drechsler, Savov, and Schnabl (2017a; b) to form consistent time series. Appendix A provides descriptions of variables used in the analyses.

For our county level lending activity, we aggregate SBL originations (total and by loan size) at the county-year level using the CRA data and use this measure as our main proxy of local community investment. In addition, we aggregate data on loans to firms with less than $\$ 1$ million in sales from the FFIEC's CRA database as an alternative measure of community investment. One potential concern with our use of the FFIEC CRA data is that we are omitting SBL originations by small commercial banks ( $\$ 100 \mathrm{M}$ to $\$ 1 \mathrm{~B}$ in total assets)

\footnotetext{
5 The FFIEC collects data on lending from regulatory reports filed by institutions in accordance with the requirements of the CRA. Specifically, all state member banks, state nonmember banks, national banks, and savings associations with assets in excess of an annually established threshold (roughly \$1 billion in constant 2005 dollars) for both of the prior two calendar years are subject to the data collection and reporting requirements of the CRA.
} 
that are not required to file Disclosure Reports under the CRA. We address this concern in our robustness section in which we use the change in SBL outstanding as a proxy for SBL originations.

The main results on the importance of bank mergers on SBL originations are based on lending by CRA banks as a proxy for overall lending in the local community. To get a sense of the change in the number of CRA banks Figure 1 shows the number of sample banks (left axis) and average size (right axis) by year. The figure shows that there has been significant consolidation in the banking sector over the sample period. The number of CRA banks declined from a peak of 1,929 in 2003 to 653 by the end of our sample period, while their mean (median) size increased steadily from \$4.5 (\$0.68) billion in 1999 to \$23.9 (\$2.3) billion in 2019 . There is a significant jump in the size of CRA banks in 2005 and 2006 that is driven by the $\$ 1$ billion threshold for CRA reporting in 2005, as smaller banks stopped reporting CRA data.

We construct our sample of bank mergers from the FDIC's Report of Changes. We exclude deals involving government assistance, those involving acquirers with assets below \$100 million (constant 2019 US\$), and those in which the target is headquartered outside of the 50 states or the District of Columbia. We combine the bank merger data with the call report and CRA data and drop deals with missing data on targets or acquirers to end with a final sample of 4,645 bank mergers involving 1,766 unique acquirers over the period 1999-2019.

For the main results, we group acquirer banks by total assets (in constant 2010 US\$s) into two categories: Large acquirers $\left(\geq \$ 10\right.$ billion); and Small acquirers $(<\$ 10$ billion $) .{ }^{6}$ Table 1 shows the distribution of the sample of mergers by acquirer and target sizes. The majority of deals involve small acquirers $(84.8 \%)$, with $15.2 \%$ of deals involving large acquirers. As reported in Table 1,98.0\% of all deals involve small targets. Figure 2 is a heat map of mergers and shows the distribution of bank mergers across states. The figure shows that bank mergers are active throughout the country, though more prevalent in certain areas. The possible effects of the reduction in the number of small banks as a result of mergers could have important negative effects on the lending to small and local firms in many communities.

\footnotetext{
${ }^{6}$ Bank size classification is based on the Dobb-Frank categorization that was established in 2010 and consistent with Minton, Stulz and Taboada (2019).
} 
We measure local market merger activity (Merger Intensity) as the target banks' share of deposits in the county. For each county, the ratio is averaged over the prior three years. The average Merger intensity is $3.0 \%$ for the 2,724 counties with mergers. To understand the effect of acquirer and target size and location on community investment, we construct separate merger intensity measures based on acquirer size and location. Merger intensity-small (large) -acquirer is the average share of county deposits of target banks involved in mergers with small (large) acquirers over the prior three years. Similarly, Merger intensity-in-state (out-ofstate) is the average share of county deposits of target banks involved in mergers with an in-state (out-of-state) acquirer over the prior three years.

Table 2 reports descriptive statistics of the main variables used in our analyses at the county-year level. The mean merger activity involving large (small) acquirers is $1.0 \%$ (1.4\%), while Merger intensity out (in)state is $1.7 \%(1.3 \%)$. The mean total value of SBL originations across county-years is $\$ 22.2$ million. $^{7}$ By size categories, the mean small $(<\$ 100 \mathrm{~K})$ and large $(\$ 250 \mathrm{~K}$ to $\$ 1 \mathrm{M}) \mathrm{SBL}$ is $\$ 8.8$ million, and $\$ 6.4$ million, respectively. To more directly capture lending to the smaller, more informationally opaque firms, as noted previously, we use the total SBL originations to firms with revenues less than $\$ 1$ million as an alternative measure to SBL originations. The mean amount of loan originations to small firms is $\$ 9.8$ million. In addition, for the average county, small SBL originations (loans to small firms) account for 35\% (40\%) of total SBL originations over the sample period. This highlights the importance of soft information processing given its relevance in small business lending.

\section{Bank mergers and small business lending at the county level}

\subsection{Methodology}

In this section, we examine how local merger activity relates to SBL originations in counties where the target bank has a presence. The analysis in this section is based on the following panel regressions analyzing SBL originations at the county level.

\footnotetext{
${ }^{7}$ In our analyses we capture SB lending as the $\log (1+$ SBL originations (in 2019 US\$ thousands). The mean amount of SBL originations is $\$ 22,246,835.46=([\exp 10.01-1] * \$ 1,000)$. We use the log $(1+\mathrm{SBL}$ originations $)$ because there are zeros in the SBL originations in some of the size categories.
} 


$$
\log (S B L)_{c, t}=\alpha+\beta \text { Merger intensity }{ }_{c, t-1}+\theta \operatorname{CONTROLS}_{c, t-1}+\gamma_{c}+\delta_{t}+\varepsilon_{i, t}
$$

where $\log (S B L)_{c, t}$ is the natural logarithm of one plus SBL originations in county $c$ in year $t$ (in $2019 \$$ thousands) given the skewness in the distribution of SBL originations (see Levine et. al., 2020). As noted in section 2, Merger intensity is the share of deposits of target banks in the county c, averaged over the prior three years. Local bank characteristics have been shown to correlate with bank lending, (see, for example, Berger et al., 2017; Boot and Thakor, 2000; Berger and Bouwman, 2009, and Bord et al., 2018). Thus, we include a set of variables (CONTROLS) that control for bank size, strategy, and risk: Bank size (log of assets), Herfindahl index of deposits (Herfindahl-deposits), Total loans-to-assets, RE loans-to-loans, C\&I loans-to-loans, Personal loans-to-loans, bank capitalization (Capital ratio), and non-performing loans-to-loans (NPL ratio). The bank characteristics are county-level averages that are weighted based on the proportion of local bank branches following Berger et al. (2017). We also include a set of county-level market conditions that may influence demand for SBL: Employment growth, Ln(population), Ln(wages), and growth in the housing price index (Change in HPI). We include county fixed effects $\left(\gamma_{c}\right)$ to control for time invariant county differences that could affect bank behavior and year fixed effects $\left(\delta_{\mathrm{t}}\right)$ to control for changes in macroeconomic conditions and technology over time. Standard errors are clustered at the county and year levels.

\subsection{Main Results}

Panel A of Table 3 shows our baseline results from the estimation of Equation 3. We show results for total, small, medium, and large SBL originations in columns (1)-(4), respectively. The results for SBL to small firms are reported in column (5). Merger intensity is positively associated with total, medium and large SBL originations. While on average, Merger intensity is not significantly associated with small SBL, it is positively associated with loans to small firms. The result is economically significant. From column (5), a one-standard deviation increase in Merger intensity (0.051) is associated with a 1.19\% increase in Log (Loans to small firms) $(\$ 116,575)^{8}$ loans to small firms.

\footnotetext{
${ }^{8}$ From Table 2, the average amount of Loans to small firms is $\$ 9,768,299.08$ [(exp $\left.{ }^{9.187}-1\right) \times$ x $\left.\$ 1,000\right]$. From column (5) of Table 3, a one-standard deviation increase in Merger intensity (0.051) is associated with a 1.19\% [0.234 x 0.051] increase in SBL originations, or $\$ 116,574.88$ [0.0119 x \$9,768,299.08].
} 
The results in Panel A of Table 3 also show that average county bank characteristics are important for SBL originations. Bank size, Herfindahl-deposits, loans-to-assets, C\&I loans-to-loans, and real estate loansto-loans are positively associated with total SBL originations. Bank size, Herfindahl-deposits, and loans-toassets are positively associated with small SBL originations and loans to small firms. Finally, population, Ln(wage), and the change in HPI are also positively correlated with SBL originations, which indicates that local community characteristics are important for SBL originations.

One potential concern with our analyses is that results from the estimation of equation (3) may not lead to causal inferences, given inherent endogeneity concerns. For instance, high demand for SBL in a county may make banks operating in the county attractive targets for an acquisition, especially if acquirers are interested in growing their SBL portfolio. Alternatively, banks in declining markets may be more likely targets in acquisitions. Thus, the observed subsequent changes in SBL originations may be a result of omitted county level factors that affect both SBL originations as well as merger activity involving targets with a presence in the county. To address these endogeneity concerns, we employ an instrumental variable strategy similar to the one used in prior studies assessing how banks' geographic diversification affects bank risk and cost of funds (Goetz, et. al., 2016; Levine et al., 2021, and Faia et al., 2019). Specifically, we instrument merger intensity using the predicted level of merger activity from a gravity equation, akin to the approach used by Frankel and Romer (1999) to examine the effects of international trade flows.

To implement the strategy, we proceed as follows. In a first-stage (the zero-stage), we estimate the following gravity equation at the state-pair-year level from 1999-2019, excluding years in which a target state did not have any bank merger activity:

$$
\text { Deals }_{i, j, t}=\alpha \operatorname{Ln}\left(\text { distance }_{i, j}+\beta \Delta \operatorname{Ln}\left(\frac{\text { population }_{j}}{\text { population }_{i}}\right)+\gamma I B \text { Index }_{i}+\delta_{t}+\theta_{j t}+\varphi_{i}+\varepsilon_{i j t}\right.
$$

Deals $_{\mathrm{ijt}}$ is the number of bank mergers involving an acquirer from state $j$ and a target from state $i$. Ln(distance) is the log of the distance (in miles) between state $i$ and state $j$. IB index is either the De novo index or the Interstate Branching Index from Rice and Strahan (2010), updated by Berger et al., (2020). ${ }^{9}$ De

\footnotetext{
${ }^{9}$ We thank Allen Berger for providing the updated data on the Interbank Branching Restrictions index.
} 
novo index is an indicator equal to one for states that prohibit de novo interstate branching in a given year and zero otherwise. $\delta_{\mathrm{t}}, \theta_{\mathrm{jt}}$, and $\phi_{\mathrm{i}}$ represent year, acquirer state-year, and target state fixed effects, respectively. We do not use target state-year fixed effects because the latter could be correlated with county small business loan growth. As in Faia et al. (2019), because we use count data (\# of deals) as the dependent variable, we estimate the above equation using Poisson Pseudo Maximum Likelihood (PPML), which unlike OLS, is robust to distribution mis-specification (Santos Silva and Tenreyro, 2006).

We then aggregate the predicted bilateral values from the above equation at the target state-year level to obtain the total predicted bank mergers for state $i$ in year $t$ (Predicted deals $s_{i, t}$ ). We the use Predicted deals $s_{i, t}$ as our instrument for Merger intensity in 2SLS regressions. Because Merger intensity is the three-year average of the share of county deposits held by target banks, we average Predicted deals $s_{i, t}$ over the prior three years.

The results of the IV approach are shown in Panel B of Table 3 using the de novo index. ${ }^{10}$ Column (1) reports first-stage results and shows that our instrument, Predicted deals $s_{i, t}$, has a strong explanatory power for Merger intensity. The Sanderson-Windmeijer (2016) multivariate $F$-test of excluded instruments $(F$ statistic of 111.07) easily rejects the null of weak instruments. The second-stage results shown in columns (2) through (6) confirm our earlier results. The instrumented Merger intensity is positively and significantly related to total, small, and medium SBL, and is also positively and significantly correlated to loans to small firms. Since our main results are robust to endogeneity concerns, we will use OLS for the remainder of the analysis, where we split the main merger intensity measure by acquirer characteristics.

\subsection{Merger intensity and acquirer size}

Based on prior research we expect that acquisition strategy driven by acquirer characteristics may be important for local SBL origination. Prior research has shown that small banks tend to specialize more in soft information-based lending where they have a competitive advantage relative to large banks (Liberti and Petersen, 2019; Berger and Black, 2011; Berger and Udell, 1995, 2002; Berger, et al., 2005; Cole, Goldberg,

\footnotetext{
${ }^{10}$ As noted above we use two approaches in our zero-stage regressions (shown in Table IA.1 of our internet appendix) to determine the predicted deals used as our instrument: one using the de novo index and another using the interstate banking activity index. The results using either approach are qualitatively similar.
} 
and White, 2004, and Berger, Bouwman and Kim, 2017). In contrast, large and more distant banks are more likely to depend on hard technology driven information (see, e.g. Petersen and Rajan, 2002).

We begin our analyses by examining whether mergers involving large acquirers have different impacts on SBL originations than those involving small acquirers. Because small firms are likely to be more opaque than larger firms and small banks have a competitive advantage in soft information-based lending, we posit that the impact of merger activity on SBL originations is likely to differ based on the acquiring bank's size. To directly assess the impact of acquirer size, we estimate equation (3) and, include Merger intensity-small (large) acquirer. As noted in section 2, Merger intensity-small (large) acquirer is the share of county deposits of target banks involved in mergers with small (large) acquirers, averaged over the prior three years.

We report the regression results in Table 4. As in Table 3, we show results for total SBL, small, medium, and large SBL originations in columns (1)-(4) and the results for loans to small firms in column (5). As shown in Table 4, the size of the acquirer is an important characteristic when examining the impact of merger activity on SBL originations. The coefficient on Merger intensity-small acquirer is positive and statistically significant across all model specifications. The impact is economically significant. Using the coefficients in column (1), a one-standard deviation increase in Merger intensity-small acquirer (0.037) is associated with a $1.9 \%$ increase in $\log (S B L)(\$ 422,690) .{ }^{11}$ In contrast, the coefficient estimates on Merger intensity-large acquirers are negative and statistically significant for total and small SBL originations, indicating that higher levels of Merger intensity-large acquirer are associated with a reduction in total and small SBL originations. As shown in column (5), mergers involving small acquirers are positively associated with loans to small firms. A one-standard deviation increase in Merger intensity-small acquirer is associated with $2.7 \%$ increase in loans to small firms. Conversely, mergers involving large acquirers are negatively associated with loans to small firms; a one-standard deviation increase in Merger intensity-large acquirer (0.029) is associated with a $1.6 \%$ decrease in loans to small firms.

\footnotetext{
${ }^{11}$ From Table 2, the average amount of SBL originations is $\$ 22,246,835$ [( $\left.\exp ^{10.010}-1\right) \times$ x $\left.\$ 1,000\right]$. From column (2) of Table 3, a one-standard deviation increase in Merger intensity-small acquirer (0.037) is associated with a $1.91 \%$ [0.516 $x$ 0.037] increase in SBL originations, or \$422,690 [0.019 x \$22,246,835].
} 
The $F$-tests indicate a significantly different impact of mergers by large and small acquirers on SBL originations across all loan size categories and on loans to small firms. These results are consistent with prior studies documenting the disadvantage that large banks have in lending to small firms, which relies on soft information-based lending technology arguments (Berger and Black, 2011; Berger, et al., 2017). Overall, the results in Table 3 show positive effects of bank mergers on small business lending while Table 4 underscore the importance of considering acquirer size when assessing the impact of bank mergers on community, as results show that primarily mergers by small acquirers drive the overall positive effects. The results suggest that mergers involving small acquirers can help support community investment through increased SBL originations and lending to smaller firms and are consistent with the view that small banks have an advantage in lending to more informationally opaque small firms.

\subsection{Merger intensity by the location of the acquirer}

The literature has shown the important role that distance plays in lending to informationally opaque small firms, as proximity between lenders and borrowers may facilitate the generation of private information (e.g. Agarwal and Hauswald, 2010; Berger and Udell, 1995; Degryse and Ongena, 2005; DeYoung et al., 2008; Nguyen, 2019). However, some evidence suggests that technological improvements have diminished the importance of distance (e.g. Petersen and Strahan, 2002). Because small firms are likely to be more opaque than larger firms and non-local banks may be less familiar with the local market, we posit that the impact of merger activity on SBL originations is likely to differ based on the acquiring bank's proximity to the target's market. Indeed, one concern for regulators related to community investment and bank mergers is that out-ofstate acquirers may be less committed to continue investing in the areas that the target bank served.

To examine the impact of distance, we estimate equation (3) and include Merger intensity-in-state and Merger intensity-out-of-state. As noted in Section 2, Merger intensity-in-state (out-of-state) is the share of county deposits of target banks involved in mergers with an acquirer headquartered in the same state (different state), averaged over the prior three years. We report results in Table 5. As in Table 4, we show results for total, small, medium, and large SBL originations and for loans to small firms. The control variables are those used in Table 4 but are not reported to conserve space. Standard errors are clustered by county and year. 
The results in Panel A of Table 5 highlight important differences on the impact of bank mergers on SBL originations associated with the location of the acquirers. The coefficient estimate on Merger intensityin-state is positive and significant at the one percent level for total, small, and medium SBL originations and loans to small firms while it is significant at the 10 percent level for large SBL originations. From the coefficients in columns (1)-(3), a one-standard deviation increase in Merger intensity-in-state (0.034) is associated with an increase of $1.3 \%$ in $\log ($ total $S B L)$ and $0.82 \% \log ($ small $S B L)$ originations and an increase of $2.44 \%$ in $\log ($ medium SBL) originations. In contrast, the coefficient on Merger intensity-out-of-state is only significant for total and medium SBL originations (columns (1 and 3)). An F-test of the equality between coefficients on Merger intensity-in-state and Merger intensity-out-of-state shows that the difference is significant for total and small SBL originations and for loans to small firms.

One of the concerns when investigating the impact of in-state versus out-of-state is that the banks may be very close in terms of distance even though they may be in different states. To address this issue, Panel B of Table 5, reports the results of regressions in which we directly measure the impact of distance between the acquirer's headquarter county and the target's county. We define short (long) distance mergers as those where the distance between the acquirer's headquarter county and the target's county is below (above) the median distance in a given year. Using this distance-based classification, we create two new measures of merger activity: Merger intensity short-distance (long distance) is the share of county deposits of target banks involved in mergers with an acquirer from a short (long) distance, averaged over the prior three years. Overall, the results for mergers involving short (long) distance acquirers are similar to those in Panel A for mergers involving in-state (out-of-state) acquirers.

The results in Table 5 on acquirer location are consistent with the idea that acquirers from more distant locations may not be as familiar with the target's local market and thus find it more difficult to process soft information that is used in lending to the informationally opaque small firms. In contrast, acquirers that are familiar with the local market and in closer proximity to the borrowers (in-state acquirers) should find it easier to overcome the difficulties inherent in lending to more opaque firms. A potential concern with this interpretation of the results is that acquirers could be headquartered in a different state or from a distant location 
but already may have established a presence in the target's state. Thus, out-of-state acquirers and long distance acquirers classified based on headquarter location or distance may not necessarily be unfamiliar with or far away from the target's market. This would lead to a different interpretation of our results.

To more directly examine whether knowledge about the local market by acquirers may drive our results, we run specifications of equation (3), using two alternate merger intensity measures: Merger intensityin-state presence, and Merger intensity-no in-state presence. In-state presence is defined based on whether the acquirer has a presence in the state of the target prior to the merger. We use the FDIC's SOD database to determine whether the acquirer had a presence (a branch) in the state of the target prior to the merger.

Panel $\mathrm{C}$ of Table 5 reports these results. The results are consistent with the current interpretation of our findings. The coefficient estimates on Merger intensity-in-state presence are positive and significant in all regression specifications. In contrast, the coefficient estimates on Merger intensity-no in-state presence are not significant across all model specifications, except for regressions using medium SBL, where the coefficient is positive and statistically significant (at the $1 \%$ level). $F$-tests of differences are significant for total and small SBL originations and for loans to small firms.

These results add support to the view that distance still matters in small business lending, consistent with recent evidence suggesting that credit markets are still local, especially for small firms (e.g., Nguyen, 2019; Wang, 2019). In addition, the results support the findings of Levine, et al. (2020) on the importance of distance in small business lending through the cost of communication of soft information. The results also support the importance of relationship lending for small businesses (Petersen and Rajan, 1994) and the role of local banks in fostering community investment.

\subsection{Merger intensity by size and location}

The two previous sub-sections examine the importance of acquirer size and location separately and show increases in SBL associated with mergers involving small acquirers and those involving acquirers in closer proximity to or in the same state as the target. In this section, we examine the impact of size and location together by including four measures of merger intensity: Merger intensity-small, instate; Merger intensity large, out-of-state, Merger intensity -small, out-of-state, and Merger intensity-large, instate. Specifically, 
Merger intensity-small (large) in-state [out-of-state] is the share of county deposits of target banks involved in mergers with a small (large) acquirer headquartered in the same state [different state], averaged over the prior three years.

Based on previous research that shows small banks have advantages in obtaining soft information and because familiarity with the local market may facilitate the collection of such information, we posit that mergers involving small acquirers in close proximity to the target's market may lead to significant increases in SBL, especially for the more opaque firms. In contrast, mergers involving large acquirers from more distant locations may lead to a reduction in lending to informationally opaque borrowers.

The results of the regressions assessing the impact of size and location together are reported in Table 6. Results show that acquirer size is more important than location when assessing the impact of mergers on SBL. The results show that mergers involving small acquirers from both in- and out-of- state are associated with significant increases in SBL (across all size categories) and in loans to small firms. The $F$-tests show no significant difference between coefficients on Merger intensity-small in-state and Merger intensity-small outof-state. The results also show that mergers involving large acquirers (from both in- and out-of-state) lead to a decrease in small SBL and loans to small firms. The $F$-tests show no significant difference between coefficients on Merger intensity-large in-state and Merger intensity-large out-of-state.

Importantly, the $F$-tests in Table 6 show a significant difference between the coefficients on Merger intensity-small in-state and Merger intensity-large out-of-state. These differences are consistent with small acquirers from the same state as the target having an advantage in collecting and processing soft information relative to large, distant acquirers that may not be as familiar with the target's local market.

\subsection{Target Choice and Bank Characteristics}

The prior section highlights the impact of local market community investment through SBL originations driven by acquisition activity by large out-of-state banks and small in-state banks. While the location or proximity of the acquirer matters, the results show that the main driver of the results is the size of the acquirer. When considering which bank to acquire, small banks could target other small banks, which also have a competitive advantage in lending to small firms to retain or build their advantage in SBL originations. 
In contrast, large banks, with less focus on SBL could target banks with different characteristics and more in line with their strategic objectives. In this section, we focus on examining whether target characteristics differ across mergers involving large and small acquirers.

To examine the importance of acquirer choice we use logit regressions where the acquirer is either a small bank or a large bank and whether the acquirer is in-state or out-of-state. We measure target characteristics one year prior to the acquisition. Table 7 shows these result of these regressions. For this analysis, we focus on small targets, which account for over $98 \%$ of all mergers in our sample. We control for the relative size of the merger ( $\log$ (acquirer assets-to-target assets)) and focus on those variables that may be informative as to the potential strategy of the acquirer. Table 7, columns (1)- (3) shows the results of small and large acquirers while columns (4)- (6) shows the results of in-state and out-of-state acquires.

One important question is whether small acquirers' advantage is driven by relationships as highlighted in the introduction in relation to the recent PPP program in response to the COVID19 pandemic. Since small banks are believed to have a competitive advantage in soft information technology, we posit that they will build on their relationship advantage by targeting small banks with a relationship advantage relative to large acquirers. We examine the differences in relationship lending measures used in the literature to identify strong relationships (see Li and Strahan, 2020). The two measures we investigate is the small business loans-to-assets and core deposits-to-assets. Column (1) shows that targets of small acquirers have higher small business loansto-assets and higher core deposits-to-assets, but lower total loans-to-assets, relative to target banks of large acquirers. This supports the argument that small acquirers target local banks to enhance their soft information technology advantage. In column (2), we include variables that reflect balance sheet strength and target profitability. The results show that relative to small acquirers, large acquirers target small banks with better profitability (higher ROA) and more focus on nontraditional banking activities (higher non-interest income to income), but with lower efficiency (higher noninterest expenses-to-assets), and lower capital. We find no difference loan quality.

One additional consideration in the acquisition decision is whether local acquirers are making similar decisions as acquirers that could be further away. Columns (4) - (6) of Table 7 show the results for in-state 
and out-of-state acquirers. The results are consistent with local acquirers focusing on a strategy to expand on their advantage in relationship banking while out-of-state acquirers focus more on expanding their nontraditional banking activities. Relative to in-state acquirers, out-of-state acquirers tend to pursue targets with significantly worse loan quality.

As prior studies have shown that small local banks tend to have a competitive advantage in lending to small businesses, the results are consistent with acquiring banks targeting those banks that enhance their competitive advantage. Small local acquirers focus on targets with higher lending to small business that tend to be less profitable. The evidence is supportive of small local acquirers focusing on a strategy that highlights small business lending, which benefits community investment and is similar to findings in Erel, Jang and Weisbach (2015) where acquiring firms target financially constrained firms to alleviate constraints. On the other hand, large banks focus on local small banks that are more profitable and focus more on nontraditional banking activities (higher ROA, ROE, and non-interest income to income) perhaps to grow the overall franchise value but not to grow SBL originations, where they do not have an advantage relative to small acquirers.

\subsection{Opaque target counties versus other target counties}

The previous sub-sections show that in-state mergers, those involving short-distance acquirers and those involving small acquirers are associated with increases in small SBL originations. In addition, the results highlight differences in the acquisition strategy of large and small acquirers, consistent with each group making decisions to enhance the respective strengths that help to drive the impact we observe. These results support the view that small local banks that possess a relative competitive advantage in SBL originations are important for community development through SBL originations. The advantage exists through the dependence on soft information for small business lending where there are informationally opaque borrowers. One potentially important aspect of what we observe are county characteristics. Since small banks have an advantage in the use of relationships and make acquisition decisions that promote this advantage, the county type may be an important consideration in investigating the impact of mergers on local SBL originations. To more directly test this idea, in Table 8 we examine whether the impact of merger intensity on SBL originations varies across 
counties based on the relative opacity of the county measured through the proportion of opaque (small) firms in the county.

We construct a measure of county-level opacity, similar to Wang (2019). Using data from the US Census Bureau's Quarterly Workforce Indicators, we compute the percentage of employment by small firms (with fewer than 50 employees) in each county. Next, we create an indicator variable, Opaque county, that equals one if the fraction of small firm employment in the county is in the top tercile of the distribution and zero otherwise. We then estimate equation (3), and include an indicator variable, Opaque county, and its interaction with the Merger intensity measure.

The results in Table 8 show that merger activity is associated with higher total and large SBL originations and with loans to small businesses in opaque counties relative to other less opaque counties: The coefficient estimates on the interaction term Merger intensity x Opaque county is positive and significant in regressions for total and large SBL and loans to small firms. Using the coefficients in column (1), a onestandard deviation increase in Merger intensity $(0.051)$ is associated with a $1.8 \%(\$ 397,106)$ increase in total SBL originations in opaque counties. ${ }^{12}$ Results in Table 8 also show that merger activity is not significantly related to small, large SBL and loans to small firms in less opaque counties. The coefficient on Merger intensity is insignificant in Models (2), (4) and (5).

In the previous section, we show that there are clear differences between large and small acquirers and the proximity of acquirers to targets in terms of the local impact on SBL originations. There are very few large acquirers in the opaque counties, limiting the power of our tests when using the separate merger intensity measures, Merger intensity-small (large) acquirer, interacted with Opaque. In results shown in Table IA.2 of our internet appendix, we estimate the regressions using these merger intensity measures and although the coefficients on the interaction term Merger intensity-small (large) acquirer x Opaque are not significant, we find a positive and significant effect of Merger intensity-small acquirer on SBL originations in opaque counties

\footnotetext{
${ }^{12}$ From column (1) Table 8, a one-standard deviation increase in Merger intensity (0.051) is associated with a $1.8 \%$ $[(0.173+0.177) \times 0.051]$ increase in small SBL in opaque counties, or $\$ 397,106[0.018 \times \$ 22,246,835]$. The increase is statistically significant ( $p$-value of $F$-test for the sum of the coefficients Merger intensity + Merger intensity x Opaque county $=0$ is 0.000 ).
} 
across all size categories (at the $1 \%$ level based on the $F$-tests of the sum of the coefficients Merger intensitysmall acquirer $x$ Opaque + Merger intensity-small acquirer $=0$ ). In contrast, we find insignificant effects of Merger intensity-large acquirer on total, medium, and large SBL originations in opaque counties, and find a negative and significant effect on small SBL originations and loans to small firms in opaque counties.

Overall, the results in this section support the importance of soft information technologies in lending to more opaque small businesses. The positive effects of mergers on SBL originations are concentrated in opaque counties, with a larger concentration of firms that do not possess detailed financial statements. In such counties, the use of soft information technology is crucial in small business lending. The results suggest that small acquirers can build on their soft information advantage in such counties, leading to increased SBL originations.

\section{County level summary and other considerations}

Overall, the results shown in Tables 4 through 8 show that the impact of merger activity on community investment through SBL originations in the county of the target depends on the acquirer size and location, as well as on the characteristics of the firms in the county. In addition, the results show that target selection is consistent with acquiring banks building on their competitive strategy when choosing targets. Small local acquirers tend to choose targets that may have weaker profitability, but focus more on small business lending, leading to more community investment than large acquirers. In this section, we will investigate other considerations that could be relevant for the interpretation of our main results of the impact of acquirer characteristics and county opacity on the relation between bank mergers and local community investment.

\subsection{Importance of top four banks}

One important question relates to the impact of the largest banks on the results. Prior studies have argued that the presence of the four largest banks has important effects on SBL originations in certain counties (see Bord et. al., 2018). In results shown in Table IA.3 of our internet appendix, we examine whether the findings hold if we exclude those counties in which the four largest national banks have a presence. ${ }^{13}$ A county

\footnotetext{
13 The four largest banks are: Bank of America, Citigroup, JP Morgan Chase, and Wells Fargo.
} 
is defined to have a top four bank's presence if the top four banks' share of deposits in the county exceeds 10\%. Specifically, we replicate results in Table 4 excluding counties with top four banks' presence. Consistent with the results in Table 4, results in Table IA.3 of our internet appendix show that after excluding counties with a presence of the top four banks, Merger intensity-small acquirer is positively associated with SBL originations (all size categories) and loans to small firms.

\subsection{Importance of small community banks}

Our result that mergers involving small acquirers (assets $<\$ 10 \mathrm{~B})$ is associated with increases in SBL originations in target counties could be driven by small community banks ( $<\$ 1$ billion) that are not required to file CRA reports. In addition, another potential concern with our use of the FFIEC CRA data is that we are omitting SBL originations by small commercial banks that are not required to file Disclosure Reports under the CRA. To assess the extent of the impact of small community banks more directly, we first estimate equation (3), decomposing Merger intensity-small acquirer into two variables: Merger intensity-acquirer $<\$ 1 B$, and Merger intensity-acquirer $\$ 1-\$ 10 B$.The results, shown in Table IA.4 of our internet appendix reveal that the small acquirer results in Table 4 are driven by acquirers with $\$ 1-\$ 10 \mathrm{~B}$ in assets. We find that the coefficient on Merger intensity- small $\$ 1-\$ 10 B$ is positive and significant across all regression specifications. In contrast, the coefficient estimate on Merger intensity small $<1 \$ B$ is positive and significant (at the $10 \%$ level) only for loans to small firms. The $F$-tests of the difference between the coefficients of the two groups of small acquirers indicate that the effect is larger for Merger intensity- small $\$ 1-\$ 10 B$, except for large SBL originations.

To account for SBL originations of small community banks, we use the annual change in SB loans outstanding from the call reports as a proxy for SBL originations for these banks. We follow Nguyen (2019) and compute the value of SBL outstanding for a given bank in a county using the proportion of the bank's total deposits held by branches in that county. We then aggregate SBL loan originations across all community banks and CRA banks at the county level and replicate results from Table 4 using this measure. Results shown in Table IA.12 of our internet appendix confirm our earlier findings and show positive and significant effect of 
Merger intensity-small acquirer on SBL originations across all size categories. 4.3

\section{Additional robustness tests}

We conduct a series of robustness checks and report them in our internet appendix. We first test the robustness of our results to alternate definition of Opaque counties. Specifically, we use two alternate proxies for Opaque counties: 1) Opaque-small population - an indicator variable equal to one if the county's population is in the bottom tercile of the distribution and zero otherwise; 2) Rural - an indicator equal to one for counties with the USDA's Rural-Urban Continuum Code (RUCC) of 8 or 9, or zero otherwise. ${ }^{14}$ Results (shown in Table IA.5 of our Internet appendix) confirm our findings in Table 8. The coefficient on the interaction term Merger intensity x Opaque -small population is positive and significant across all model specifications, while the coefficient on Merger intensity $\mathrm{x}$ Rural is positive and significant for total, small SBL originations, and loans to small firms. Results show that the impact of bank mergers on SBL originations is stronger in opaque counties.

We also assess the effect of the change in the CRA reporting threshold (in 2005) that led to a significant increase in the size of reporting banks (Figure 1). To determine the impact of this change on our results, in Tables IA.6 and IA.7 of our internet appendix, we report results replicating those in Tables 4 and 5, respectively, for the period 2006-2019. The results confirm our prior findings and show that mergers involving small and in-state acquirers lead to increases in SBL originations and in loans to small firms.

Finally, we examine whether the global financial crisis may have led to changes in the impact of mergers on SBL originations. To examine this, we estimate equation (3) for the pre (2002-2006) and postcrisis period (2010-2019). We show results in Table IA.8 of our internet appendix. During the pre-crisis period, Merger intensity-small acquirer is positively associated with total, small SBL originations and loans to small firms. Results strengthen somewhat in the post-crisis period, as the coefficient on Merger intensitysmall acquirer is positive and significant across all regressions specifications. Overall, we find little change in our results post-crisis.

\footnotetext{
${ }^{14}$ The USDA's RUCC codes 8 (9) define non-metro areas as completely rural or less than 2,500 urban population, adjacent (not adjacent) to a metro area.
} 


\section{Bank mergers and small business lending at the bank level post-merger}

In the previous sections, we document the importance of bank merger characteristics on community investment by investigating the impact on SBL originations at the county level. We find that not only do bank mergers affect community investment, but the effect varies depending on bank and community characteristics. In addition, acquirer strategy is important for target choice and differs by the acquirer size and proximity to the target. An important concern for regulators when assessing the impact of mergers is the potential decrease in community investment through SBLs by banks post-merger. In this section, we investigate explicitly changes in SBL originations by bank acquirers and other banks post-merger in the counties where the target had a presence, which is relevant to understanding the local market small business investment effect and the impact on acquirer strategy.

To do so, we aggregate SBL originations for targets and acquirers at the county level in the target's county. We restrict our analysis to lending activity in the county with the largest concentration of target's deposits pre-merger $(t-1) .{ }^{15}$ We start by creating a pro-forma bank prior to the merger aggregating the balance sheets and SBL originations (from CRA reports) of target and acquirer banks from $t-3$ to $t-1$ relative to the merger. We obtain SBL originations data for the acquirer (surviving institution) through $t+3$ in the target's county. We drop deals with missing county-level SBL data for the pro-forma acquirer in either the pre- or post-merger period.

Next, for each deal, we match each pro-forma acquirer to a bank of similar size (a bank in the same size group that is within $30 \%$ of the acquirer's asset size as of $t-1$ ) that is not involved in a merger, ${ }^{16}$ but has a lending presence in the target's county. We first match by size and then by the proportion of small business loans outstanding as of $t-1$. We end up with a final matched sample of 889 deals involving 414 acquirers.

\footnotetext{
${ }^{15}$ In our sample of 4,645 mergers, target banks held an average of $81 \%$ of their deposits in the county where they had the largest presence (largest concentration of deposits). In 91\% (4,246) of the deals, the target had the largest presence in the county of its headquarter.

${ }^{16}$ For each merger, we define control banks as those banks not involved in a merger during a six-year window around the merger $[t-3, t+3]$.
} 
Using the matched sample, we assess the changes in SBL originations by the merged bank post-merger using the following DiD design where we restrict our analyses to three years before and after the merger $[-3,+3]$ :

$$
\log (S B L)_{i, c, t}=\alpha+\beta_{1} \text { Treat }+\beta_{2} \text { Post } \times \text { Treat }+\mathrm{Z}_{i, t-1}+X_{c, t-1}+\theta_{c}+\delta_{t}+\varepsilon_{j, t}
$$

where, $\log (\mathrm{SBL})_{\mathrm{i}, \mathrm{c}, \mathrm{i}}$ is the natural $\log$ of one plus the amount of SBL originations for bank $i$ in county $c$ in year t. Treat is an indicator that equals one for the pro-forma acquirers and zero otherwise. Post is as indicator equal to one starting the year after the merger. $Z_{\mathrm{i}, \mathrm{t}-1}$ is a vector of bank-level controls that includes: Size; Loansto-assets; RE loans; C\&I loans; Personal loans, Capital ratio, and NPL ratio. $\mathrm{X}_{\mathrm{c}, \mathrm{t}-1}$ is a vector of county level controls including Herfindahl-deposits; Employment growth, Ln(population), Ln(wages), and Growth in the housing price index. $\theta_{\mathrm{c}}$ and $\delta_{\mathrm{t}}$ are county and year fixed effects, respectively. We cluster standard errors at the county and year levels. ${ }^{17}$ We run various specifications of equation (5) using the sample of mergers by small and large acquirers, respectively.

We first assess the quality of our matches by comparing characteristics of pro-forma acquirers and their controls in Appendix B. The results show that there is no difference in size, proportion of SB loans, or asset quality (NPL ratio) across the two groups. Interestingly, there are differences in the make-up of the balance sheets across treated and control banks. The control banks have a higher capital ratio and the difference is significant at the $1 \%$ level. In terms of lending behavior, control banks have lower proportion of real estate loans but C\&I and personal loans comprise a larger share of their loan portfolio relative to the treated banks, all significant at the $1 \%$ level. We control for these characteristics in our regressions. We also examine the validity of the parallel trends assumption underlying our DiD specification. In Table IA.9 of our internet appendix, we report results from estimations of equation (5) using interactions between Treat, and various timing indicators, $t-2, \mathrm{t}-1, \mathrm{t}, \mathrm{t}+1$ and $\mathrm{t}>=+2$, relative to the year of the merger. Results show that $\mathrm{SBL}$ originations by treated and control banks follow parallel trends in the pre-merger period (insignificant coefficients on the interaction terms, t-2 and t-1 x Treat). The effect on SBL originations begins in the year of the merger, as the coefficients on the interaction terms ( $t, t+1$ and $t>=2 \times$ Treat) are positive and significant.

\footnotetext{
${ }^{17}$ We obtain similar results using alternate clustering schemes, such as clustering by bank and year.
} 
In Table 9 we show descriptive statistics of changes in SBL originations $(\Delta \log (\operatorname{SBL}))$ for large and small acquirers pre- and post-merger. Given our interest in assessing the impact on community investment, which involves smaller firms, we report the changes in total, small SBL originations and loan originations to small firms for small and large acquirers pre- and post-merger. We report statistics for all mergers, in-state and out-of-state mergers, and mergers in opaque counties. The univariate analyses reveal that the change in SBL, small SBL and loans to small firms post-merger is larger for small acquirers than for large acquirers. These differences are larger in magnitude for mergers in more opaque counties. These preliminary results corroborate our findings in the county level analyses and further support the view that small banks have advantages in lending to informationally opaque borrowers that affect community investment.

We formally examine changes in lending activity post-merger by large and small acquirers by estimating equation (5) using our matched sample. The results are shown in Table 10. We report results for total, small, medium, and large SBL originations, as well as for loans to small firms. We show results using the matched sample of deals involving small (large) acquirers in Panel A (B).

The results in Panel A show that small acquirers significantly increase SBL originations post-merger relative to the control banks. The coefficients on the interaction term Post $\mathrm{x}$ Treat are significant across all model specifications. The results are statistically and economically significant. Taking the coefficients from column (2), results reveal a.0.751 higher increase in small SBL originations by small acquirers post-merger relative to the control sample, which represents an $11.8 \%$ increase relative to its mean (6.39). Post-merger, small SBL originations by small acquirers are $7.56 \%$ higher relative to the control group. ${ }^{18}$ This is consistent with an increase in local community investment and small acquirers expanding on their small business investment advantage through mergers.

In contrast to the results for small acquirers, results for large acquirers in Panel B of Table 10 do not show any significant difference in SBL originations post-merger for large acquirers relative to the control group. The coefficients on the interaction term Post $\mathrm{x}$ Treat are insignificant across all model specifications

\footnotetext{
${ }^{18}$ From column (2) in Panel A of Table 9, Post merger, small SBL originations by small acquirers are $0.483(0.751+-$ 0.268 ) higher relative to the control sample, which represents $7.56 \%$ of its mean value for this subsample (6.39)
} 
involving large acquirers. These results corroborate our main findings at the county level and suggest that there are benefits from mergers involving small acquirers in terms of SBL originations that are not present with large acquirers.

In results shown in Table IA.10 of our internet appendix, we replicate the results in columns (1) and (2) of Panel A of Table 10, running separate regressions for in-state mergers and out-of-state mergers, as well as for mergers in opaque and less opaque counties. Our results show that the increase in total and small SBL originations for small acquirers post-merger is driven by in-state mergers. We also find increases in total SBL and small SBL originations for small acquirers in mergers in both opaque counties and less opaque counties, although the magnitude of the increase is larger in opaque counties. Differentiating by location or by county opacity does not alter the results for large acquirers. We find little evidence of changes in SBL originations post-merger for large acquirers.

As a final test, we examine the reaction of competitor banks in the target county to get a full understanding of the community investment effect of bank mergers. To assess the competitors' reaction, we examine post-merger SBL originations by banks with a presence in the county that are not involved in the merger. Specifically, we aggregate SBL originations across all competitor banks (those not involved in the merger) in the county in the six-year window around the merger $[-3,+3]$. Using the total SBL originations, we estimate regressions similar to equation (5) using the indicator Post. The coefficient on Post thus captures the change in SBL originations post-merger for competitor banks.

In results shown in Table IA.11 of our internet appendix, we find that that competitors decrease total, small, medium SBL originations and loans to small firms post-merger when small acquirers are involved in the mergers. The coefficient on Post is negative and significant across all model specifications except when using large SBL. For regressions using small SBL, Post is weakly significant (at the $10 \%$ level).

The magnitude of the results is smaller than those assessing the change in SBL originations by small acquirers. Taken together, results suggest that the increase in SBL originations in target counties following mergers involving small acquirers is largely attributed to increased post-merger lending activity by small acquirers. Similar to our prior results, the results highlight the importance of acquirer size, acquirer location, 
and county characteristics in assessing the impact of mergers on local community investment made through small business lending. Importantly, banks seem to expand on strategies consistent with target choice. Large acquirer banks reduce SBL originations while small banks tend to expand SBL originations. In addition, the small banks' expansion in SBL originations seem to increase their local market power, leading to a reduction in local SBL originations by local competitors.

\section{Conclusion}

The paper investigates the impact of bank mergers on community investment through an evaluation of SBL originations. Specifically, we examine the importance of acquirer size, proximity, and the types of firms in a county (opacity). In addition, the paper examines the importance of acquirer's target choice across acquirer characteristics. The paper then analyses the outcome of the acquisition on acquirer strategy and local community investment.

Merger intensity has a positive influence on SBL originations in the target market. This is driven by the impact of small acquirers where mergers involving small and in-state acquirers are positively associated with SBL originations, especially for small SBLs and loans to small firms. In contrast, we find adverse effects (decreases in SBL originations) associated with mergers involving large acquirers and find no impact on SBL originations for mergers involving out-of-state acquirers. Together, these findings add support to the view that small local acquirers may have a comparative advantage in using soft information technologies in lending to informationally opaque small firms relative to large out-of-state acquirers.

Importantly, we investigate acquirers' target choices and show that acquiring banks target local banks to expand on their strategies. Large banks tend to target banks with stronger balance sheets that focus less on loans to small firms. Conversely, small acquirers target local banks that have weaker balance sheets but have soft information technology that creates a competitive advantage in small business lending. In addition, we find evidence that mergers involving small local acquirers lead to higher SBL originations in opaque counties (counties with a large proportion of small firms), with stronger results for small SBL originations. In contrast, 
mergers involving large or out-of-state acquirers do not significantly affect SBL originations in either opaque or less opaque counties.

Finally, we investigate explicitly changes in SBL originations by bank acquirers and other banks postmerger in the counties where the target had a presence. SBL originations increase post-merger for small acquirer banks relative to the control group, especially for in-state mergers and mergers in opaque counties. We find no change in SBL originations post-merger for large acquirers. For incumbent banks, we show that they decrease small SBL originations after mergers involving large acquirers and document a decrease in SBL originations for incumbent banks for all except large loan sizes and for small firms following acquisitions by small acquirers. This decrease by incumbent banks does not completely offset the increase by small acquirers post-merger.

Overall, the results underscore the importance of examining acquirers' characteristics and strategies when assessing the impact of bank mergers on community investment. The findings in this paper have important implications for community investment resulting from bank mergers, especially those involving small banks and support the importance soft-information technologies used in lending to informationally opaque small businesses. The importance of banking relationships has been highlighted during the COVID19 crisis where small banks played a key role in providing support to local small business through the PPP. Additionally, the results have important implications for policy makers as they examine the impact of bank mergers on small business lending and general community investment and job creation. In particular, onesize-fits-all solutions are not likely to lead to common outcomes at the local level. Our results suggest that encouraging mergers by small banks and by in-state acquirers may have positive effects on small business lending and community investment, especially in areas with a large presence of small firms. 


\section{References}

Acharya, V., Berger, A. N., and Roman, R. A. 2018, Lending implications of US bank stress tests: Costs or benefits? Journal of Financial Intermediation 34, 58-90.

Agarwal, S. and Hauswald, R. 2010. Distance and private information in lending. Review of Financial Studies 23(7), pp. 2757-2788.

Balyuk, T., Berger, A.N., and Hackney, J. 2020. What is fueling FinTech lending? The role of banking market structure. Unpublished working paper.

Berger, A. N., Black, L. 2011. Bank size, lending technologies, and small business finance. Journal of Banking and Finance 35, 724-735.

Berger, A. N., Bouwman, C. H. S., and Kim, D. 2017. Small bank comparative advantages in alleviating financial constraints and providing liquidity insurance over time. Review of Financial Studies 30, 34163454.

Berger, A. N., and Bouwman, C. H. S. 2009. Bank liquidity creation. Review of Financial Studies 22, 3779837.

Berger, A., El Ghoul, S., Guedhami O., and Roman, R. A. 2020. Deregulation and banks' cost of equity capital. Unpublished working Paper.

Berger, A. N., Goulding, W. and Rice, T. 2014. Do small businesses still prefer community banks? Journal of Banking \& Finance 44, pp. 264-278.

Berger, A.N., Miller, N.H., Petersen, M.A., Rajan, R.G., Stein, J.C., 2005. Does function follow organizational form? Evidence from the lending practices of large and small banks. Journal of Financial Economics 76, 237-269.

Berger, A. N., Rosen, R. J., and Udell, G. F. 2007. Does market size structure affect competition? The case of small business lending. Journal of Banking \& Finance 31(1), 11-33.

Berger, A. N., Saunders, A., Scalise, J. M., and Udell, G. F. 1998. The effects of bank mergers and acquisitions on small business lending. Journal of Financial Economics 50, 187-229.

Berger, A. N., and Udell, G. F. 1995. Relationship lending and lines of credit in small firm finance. Journal of Business 68 (3): 351-81.

Berger A.N., Udell, G. F. 2002. Small business credit availability and relationship lending: The importance of bank organizational structure. Economic Journal 112, 32-53.

Boot, A. W. A., and A. V. Thakor. 2000. Can relationship banking survive competition? The Journal of Finance 55, 679-713.

Bord, V.M., V. Ivashina, and R. D. Taliaferro. 2018. Large banks and small firm lending. NBER working paper.

Chen, B. S., Hanson, S. G., and Stein, J. C. 2017. The decline of big-bank lending to small business: Dynamic impacts on local credit and labor markets. NBER Working Paper No. 23843. 
Cole, R.A., Goldberg, L. G., and White, L. J. 2004. Cookie cutter vs. character: The micro structure of small business lending by large and small banks. Journal of Financial and Quantitative Analysis 39, 227-251.

Cortés, K. R., Demyanyk, Y., Li, L., Loutskina, E., and Strahan, P.E. 2020. Stress tests and small business lending. Journal of Financial Economics 136, 260-279.

Degryse, H., Ongena, S., 2005. Distance, lending relationships, and competition. Journal of Finance 60, 231266.

DeYoung, R., Glennon, D. and Nigro, P. 2008. Borrower-lender distance, credit scoring, and loan performance: Evidence from informational-opaque small business borrowers. Journal of Financial Intermediation 17(1), 113-143.

Drechsler, I., Savov, A., and Schnabl, P. 2017a. The deposits channel of monetary policy. Quarterly Journal of Economics 132, 1819-1876.

Drechsler, I., Savov, A., and Schnabl, P. 2017b. Banking on deposits: Maturity transformation without interest rate risk. NBER Working Paper No.w24582.

Erel, I., Jang, Y., and Weisbach, M. 2015. Do acquisitions relieve target firms' financial constraints? Journal of Finance 70, 289-328.

Faia, E., Laffitte, S., and Ottaviano, G. 2019. Foreign expansion, competition and bank risk. Journal of International Economics 118, 179-199.

Frankel, J., Romer, D., 1999. Does trade cause growth? American Economic Review 89 (3), 379-399.

Goetz, M., Laeven, L. and R. Levine. 2016. Does the geographic expansion of banks reduce risk?" Journal of Financial Economics, 120(2), 346-362.

Jagtiani, J., Kotliar, I. and Maingi, R. Q. 2016. Community banking mergers and their impact on small business lending. Journal of Financial Services Research 27, 106-212.

Jayaratne, J. and Wolken, J. 1999. How important are small banks to small business lending? New evidence from a survey of small firms. Journal of Banking \& Finance 23(2-4), 427-458.

Keeton, W. R. 1995. Multi-office bank lending to small businesses: Some new evidence. Federal Reserve Bank of Kansas City Economic Review 80(2), 45-57.

Levine, R., Lin, C., Peng, Q, and Xie W. 2020, Communication within banking organizations and small business lending. Review of Financial Studies 33 (12), 5750-5783..

Levine, R., Lin, C., and Xie W. 2021. Geographic diversification and banks' funding costs. Management Science 67(5), 2657-2678.

Liberti, J. M., Petersen, M.A. 2019. Information: Hard and soft. Review of Corporate Finance Studies 8(1), 141.

Li, L and Strahan, P.E. 2020. Who supplies PPP loans (and does it matter)? Banks, Relationships and the COVID crisis. SSRN.3710929. 
Minton, B. A. Stulz, R. M., and Taboada, A.G. 2019. Are the largest banks valued more highly? The Review of Financial Studies, 32 (12), 4604-4652.

Nguyen, H-L. Q. 2019. Are credit markets still local? Evidence from branch closings. American Economic Journal: Applied Economics 11, 1-32.

Peek, J., and Rosengren E. S. 1998. Bank consolidation and small business lending: It's not just bank size that matters. Journal of Banking and Finance 22, 799-819.

Petersen, M. A., and Rajan, R. G. 1994. The benefits of lending relationships: Evidence from small business data. Journal of Finance 49(1), 3-37.

Petersen, M. A., and Rajan, R. G. 2002. Does distance still matter? The information revolution in small business lending. Journal of Finance 57 (6): 2533-2570.

Rice, T., and Strahan, P. E. (2010). Does credit competition affect small-firm finance? Journal of Finance, 65 , 861-889.

Sanderson, E. and Windmeijer, F. 2016. A weak instrument F-test in linear IV models with multiple endogenous variables. Journal of Econometrics 190 (2), 212-221.

Santos Silva, J. M. C. and Tenreyro, S. 2006. The log of gravity. The Review of Economics and Statistics 88 (4), 641-658.

Stein, J. C., 2002. Information production and capital allocation: Decentralized versus hierarchical firms. Journal of Finance 57, 1891-1921.

Strahan, P. E., and Weston, J. P. 1996. Small business lending and bank consolidation: Is there cause for concern? Current Issues in Economics and Finance 2, 1-6.

Strahan, P. E., and Weston, J. P. 1998. Small business lending and the changing structure of the banking industry. Journal of Banking and Finance 22, 821-845.

Strahan, P. E. 2017. Are concentrated banks better informed than diversified ones? Journal of Accounting \& Economics 64(2/3), 278-283.

Wang, T. 2019. To build or to buy? The role of local information in credit market development. Management Science. 65 (12), 5449-5956. 
Table 1. Banks mergers by acquirer size.

The table shows the distribution of bank mergers between 1999 and 2019 by acquirer size. Our sample consists of bank mergers involving acquirers with assets $>\$ 100$ million. Data on bank mergers were obtained from the FDIC Report of Changes. We exclude deals that involve government assistance and those with missing financial data on targets or acquirers from the Call Reports. Large (small) acquirers are those with assets $\geq(<) \$ 10$ billion (in constant 2010 US\$ billion).

\begin{tabular}{cccccc}
\hline \multicolumn{7}{c}{ Number of Mergers by Acquirer and Target Size } \\
\hline Year & Total & Large acquirers & \multicolumn{2}{c}{ Small acquirers } \\
Large target & Small target & Large target & Small target \\
\hline 1999 & 125 & 3 & 25 & 0 & 97 \\
2000 & 387 & 7 & 99 & 0 & 281 \\
2001 & 277 & 7 & 74 & 3 & 193 \\
2002 & 230 & 4 & 37 & 0 & 189 \\
2003 & 183 & 5 & 39 & 0 & 139 \\
2004 & 226 & 8 & 31 & 0 & 187 \\
2005 & 237 & 7 & 25 & 1 & 204 \\
2006 & 260 & 6 & 40 & 0 & 214 \\
2007 & 243 & 7 & 41 & 0 & 195 \\
2008 & 229 & 5 & 39 & 0 & 185 \\
2009 & 121 & 2 & 10 & 0 & 109 \\
2010 & 148 & 2 & 8 & 0 & 138 \\
2011 & 145 & 2 & 13 & 1 & 129 \\
2012 & 186 & 2 & 15 & 0 & 169 \\
2013 & 206 & 1 & 13 & 0 & 192 \\
2014 & 251 & 1 & 20 & 1 & 229 \\
2015 & 282 & 6 & 18 & 0 & 258 \\
2016 & 228 & 2 & 9 & 0 & 217 \\
2017 & 214 & 2 & 14 & 0 & 198 \\
2018 & 246 & 1 & 18 & 0 & 227 \\
2019 & 221 & 6 & 30 & 1 & 184 \\
\hline TOTAL & $\mathbf{4 , 6 4 5}$ & $\mathbf{8 6}$ & $\mathbf{6 1 8}$ & $\mathbf{7}$ & $\mathbf{3 9 3 4}$ \\
\hline
\end{tabular}


Table 2. Descriptive Statistics

The table provides descriptive statistics of the main county-level variables used in our analyses. Small SBL are loans with amounts < $\$ 100 \mathrm{~K}$; Medium SBL are those between $\$ 100 \mathrm{~K}$ and $\$ 250 \mathrm{~K}$, and Large SBL are those between $\$ 250 \mathrm{~K}$ and $\$ 1 \mathrm{M}$. Merger intensity is the share of county deposits of target banks involved in mergers, averaged over the prior three years. We compute this measure separately for mergers involving large and small acquirers as well as mergers with in-state and out-of-state acquirers. Opaque county is an indicator equal to one if the fraction of small ( $<50$ employees) firm employment in the county is in the top tercile of the distribution and zero otherwise. Bank size and performance variables are weighted averages computed across all banks in the county, using the proportion of banks' local branches as weights. Change in HPI is the growth in the Housing Price index. Ln(wages) is natural log of the average real wages (wages and salaries divided by total wage and salary employment) in the county. All variables are defined in Appendix A.

\begin{tabular}{|c|c|c|c|c|c|}
\hline & \multicolumn{3}{|c|}{ County-Level Variables } & \multirow[b]{2}{*}{ Max } & \multirow[b]{2}{*}{ Std. dev. } \\
\hline & $\mathrm{N}$ & Mean & Min. & & \\
\hline \multicolumn{6}{|l|}{ Merger activity } \\
\hline Merger intensity & 47,249 & 0.030 & 0.000 & 0.667 & 0.051 \\
\hline Merger intensity-large acquirer & 47,249 & 0.010 & 0.000 & 0.615 & 0.029 \\
\hline Merger intensity-small acquirer & 47,249 & 0.014 & 0.000 & 0.667 & 0.037 \\
\hline Merger intensity-in-state & 47,249 & 0.013 & 0.000 & 0.667 & 0.034 \\
\hline Merger intensity-out-of-state & 47,249 & 0.017 & 0.000 & 0.619 & 0.039 \\
\hline \multicolumn{6}{|l|}{ Community investment } \\
\hline $\log (\mathrm{SBL})$ & 47,250 & 10.010 & 3.956 & 16.592 & 1.694 \\
\hline Log (Small SBL) & 47,250 & 9.081 & 3.956 & 16.033 & 1.551 \\
\hline Log (Medium SBL) & 47,250 & 8.008 & 0.000 & 14.259 & 2.288 \\
\hline Log (Large SBL) & 47,250 & 8.759 & 0.000 & 15.564 & 2.727 \\
\hline $\log$ ( Loans to small firms) & 47250 & 9.187 & 1.509 & 15.678 & 1.698 \\
\hline \multicolumn{6}{|l|}{ County opacity measure } \\
\hline Opaque county & 46,482 & 0.348 & 0.000 & 1.000 & 0.476 \\
\hline \multicolumn{6}{|l|}{ Controls } \\
\hline Log (bank assets) & 47,250 & 16.995 & 9.916 & 21.117 & 2.543 \\
\hline Herfindahl- deposits & 47,250 & $2,735.773$ & 435.502 & $10,000.000$ & $1,558.277$ \\
\hline Loans-to-assets & 47,250 & 0.633 & 0.267 & 0.907 & 0.069 \\
\hline RE loans-to-loans & 47,250 & 0.670 & 0.134 & 0.985 & 0.100 \\
\hline CI loans-to-loans & 47,250 & 0.149 & 0.000 & 0.569 & 0.049 \\
\hline Personal loans-to-loans & 47,250 & 0.091 & 0.001 & 0.900 & 0.041 \\
\hline Capital ratio & 47,250 & 0.106 & 0.022 & 0.361 & 0.015 \\
\hline Nonperforming loans-to-loans & 47,250 & 0.014 & 0.000 & 0.190 & 0.015 \\
\hline Employment growth t-1 & 47,250 & 0.005 & -0.421 & 0.995 & 0.030 \\
\hline $\ln$ (population) & 47,250 & 10.590 & 6.441 & 16.129 & 1.284 \\
\hline $\operatorname{Ln}($ wage $) \mathrm{t}-1$ & 47,250 & 13.097 & 8.669 & 19.566 & 1.566 \\
\hline Change in HPI t-1 & 47,250 & 2.436 & -40.720 & 56.070 & 5.722 \\
\hline
\end{tabular}


Table 3. Small business lending and bank mergers at the county level

This table reports the results of regressions estimating the determinants of small business lending at the county level. Small SBL are loans with amounts $<\$ 100 \mathrm{~K}$; Medium SBL are those between $\$ 100 \mathrm{~K}$ and $\$ 250 \mathrm{~K}$, and Large SBL are those between $\$ 250 \mathrm{~K}$ and $\$ 1 \mathrm{M}$. Loans to small firms are loans to firms with revenues $<\$ 1$ million. Our key explanatory variable is Merger intensitythe share of county deposits of target banks involved in mergers, averaged over the prior three years. In Panel B, we show results from 2SLS regressions using an instrument, Predicted Deals- the predicted merger activity in a state estimated from bilateral statepair-year regressions of bank mergers involving acquirers from state $s$ and targets from state $i$. Controls (unreported in Panel B to conserve space) include: Herfindahl-deposits; Log(bank assets); Loans-to-assets; RE loans-to-loans; C\&I loans-to-loans; Personal loans-to-loans; Capital ratio; Nonperforming loans-to-loans; Ln(population), Ln(wages), Change in HPI (\%), and Employment growth. We rescale Herfindahl-deposits (dividing it by 1000) in the regressions. We construct the county-level bank characteristics as deposit-weighted averages across all banks in the county using the bank's proportion of local branches as weights. The last row in Panel B reports the Sanderson-Windmeijer (2016) multivariate $F$-test of excluded instruments. Standard errors are clustered at the county and year level. $t$-statistics are reported in parentheses. All variables are defined in Appendix A. *** $(* *)\{*\}$ denotes significance at the $1 \%(5 \%)\{10 \%\}$ level.

\begin{tabular}{|c|c|c|c|c|c|}
\hline \multicolumn{6}{|c|}{ Panel A. Merger intensity. } \\
\hline Dependent variable (Log): & SBL & Small SBL & Medium SBL & Large SBL & Loans to small firms \\
\hline & $(1)$ & $(2)$ & $(3)$ & (4) & $(5)$ \\
\hline Merger intensity & $\begin{array}{c}0.248 * * * \\
(3.62)\end{array}$ & $\begin{array}{l}0.100 \\
(1.64)\end{array}$ & $\begin{array}{c}0.640 * * * \\
(4.03)\end{array}$ & $\begin{array}{c}0.423 * * \\
(2.07)\end{array}$ & $\begin{array}{c}0.234 * * \\
(2.26)\end{array}$ \\
\hline Log (bank assets) & $\begin{array}{c}0.031 * * * \\
(4.80)\end{array}$ & $\begin{array}{c}0.032 * * * \\
(5.17)\end{array}$ & $\begin{array}{c}0.051 * * * \\
(4.10)\end{array}$ & $\begin{array}{c}0.068 * * * \\
(3.94)\end{array}$ & $\begin{array}{c}0.031 * * * \\
(3.68)\end{array}$ \\
\hline Herfindahl- deposits & $\begin{array}{c}0.025 * * * \\
(3.24)\end{array}$ & $\begin{array}{c}0.021 * * * \\
(3.24)\end{array}$ & $\begin{array}{l}0.021 \\
(1.27)\end{array}$ & $\begin{array}{l}0.024 \\
(0.97)\end{array}$ & $\begin{array}{c}0.029 * * * \\
(3.04)\end{array}$ \\
\hline Loans-to-assets & $\begin{array}{c}0.384 * * * \\
(3.44)\end{array}$ & $\begin{array}{c}0.434 * * * \\
(4.82)\end{array}$ & $\begin{array}{l}0.396 \\
(1.73)\end{array}$ & $\begin{array}{c}0.559 * \\
(1.76)\end{array}$ & $\begin{array}{c}0.582 * * * \\
(4.11)\end{array}$ \\
\hline RE loans-to-loans & $\begin{array}{c}0.784 * * * * \\
(4.33)\end{array}$ & $\begin{array}{l}0.112 \\
(0.99)\end{array}$ & $\begin{array}{c}1.967 * * * \\
(3.81)\end{array}$ & $\begin{array}{c}2.711 * * * \\
(4.51)\end{array}$ & $\begin{array}{c}0.712 * * * \\
(3.37)\end{array}$ \\
\hline CI loans-to-loans & $\begin{array}{c}0.582 * * \\
(2.33)\end{array}$ & $\begin{array}{l}-0.014 \\
(-0.07)\end{array}$ & $\begin{array}{c}1.685^{* *} \\
(2.74)\end{array}$ & $\begin{array}{c}1.851 * * * \\
(3.01)\end{array}$ & $\begin{array}{c}0.600 * * \\
(2.12)\end{array}$ \\
\hline Personal loans-to-loans & $\begin{array}{l}0.319 \\
(1.68)\end{array}$ & $\begin{array}{l}0.267 \\
(1.46)\end{array}$ & $\begin{array}{l}1.007 * \\
(1.91)\end{array}$ & $\begin{array}{c}1.404 * * \\
(2.25)\end{array}$ & $\begin{array}{l}0.307 \\
(1.27)\end{array}$ \\
\hline Capital ratio & $\begin{array}{l}0.258 \\
(0.64)\end{array}$ & $\begin{array}{l}0.298 \\
(0.93)\end{array}$ & $\begin{array}{l}0.731 \\
(0.71)\end{array}$ & $\begin{array}{l}-0.222 \\
(-0.20)\end{array}$ & $\begin{array}{l}-0.562 \\
(-1.15)\end{array}$ \\
\hline Nonperforming loans-to-loans & $\begin{array}{l}0.425 \\
(0.81)\end{array}$ & $\begin{array}{l}0.255 \\
(0.63)\end{array}$ & $\begin{array}{l}0.902 \\
(0.60)\end{array}$ & $\begin{array}{l}2.877^{*} \\
(1.95)\end{array}$ & $\begin{array}{l}0.561 \\
(0.85)\end{array}$ \\
\hline Employment growth t-1 & $\begin{array}{l}-0.033 \\
(-0.27)\end{array}$ & $\begin{array}{l}0.095 \\
(0.87)\end{array}$ & $\begin{array}{l}-0.317 \\
(-0.99)\end{array}$ & $\begin{array}{l}-0.183 \\
(-0.58)\end{array}$ & $\begin{array}{c}-0.232 * \\
(-1.93)\end{array}$ \\
\hline $\ln$ (population) & $\begin{array}{c}0.600 * * * \\
(7.48)\end{array}$ & $\begin{array}{c}0.965 * * * \\
(10.81)\end{array}$ & $\begin{array}{l}0.127 \\
(0.57)\end{array}$ & $\begin{array}{l}0.380 \\
(1.34)\end{array}$ & $\begin{array}{c}0.650 * * * \\
(6.86)\end{array}$ \\
\hline Ln(wage) t-1 & $\begin{array}{c}0.405 * * * \\
(7.01)\end{array}$ & $\begin{array}{c}0.259 * * * \\
(5.82)\end{array}$ & $\begin{array}{c}0.759 * * * \\
(7.06)\end{array}$ & $\begin{array}{c}0.661 * * * \\
(5.04)\end{array}$ & $\begin{array}{c}0.400 * * * \\
(6.14)\end{array}$ \\
\hline Change in HPI t-1 & $\begin{array}{c}0.002 * * * \\
(2.91)\end{array}$ & $\begin{array}{c}0.001 * \\
(2.04)\end{array}$ & $\begin{array}{l}0.001 \\
(0.44)\end{array}$ & $\begin{array}{c}0.005^{*} \\
(1.88)\end{array}$ & $\begin{array}{c}0.002 * * \\
(2.30)\end{array}$ \\
\hline County fixed effects & Yes & Yes & Yes & Yes & Yes \\
\hline Year fixed effects & Yes & Yes & Yes & Yes & Yes \\
\hline Observations & 47,248 & 47,248 & 47,248 & 47,248 & 47,248 \\
\hline Adjusted $\mathrm{R}^{2}$ & 0.964 & 0.976 & 0.784 & 0.749 & 0.943 \\
\hline
\end{tabular}


Table 3. Small business lending and bank mergers at the county level. Continued.

\begin{tabular}{lcccccc}
\hline & \multicolumn{5}{c}{ Panel B. 2SLS Results. } \\
\hline Dependent variable: & Merger intensity & SBL & Small SBL & Medium SBL & Large SBL & Loans to small firms \\
\hline & $(1)$ & $(2)$ & $(3)$ & $(4)$ & $(5)$ & $(6)$ \\
Merger intensity (IV) & First-stage & & & Second-stage & & $1.649^{* *}$ \\
& & $1.531^{* *}$ & $0.904^{*}$ & $3.482^{* *}$ & 1.415 & $(2.04)$ \\
Predicted Deals & & $(2.41)$ & $(1.71)$ & $(2.04)$ & $(0.72)$ & \\
& $0.007^{* * *}$ & & & & & Yes \\
Controls & $(10.54)$ & Yes & Yes & Yes & Yes & Yes \\
County fixed effects & Yes & Yes & Yes & Yes & Yes & Yes \\
Year fixed effects & Yes & Yes & Yes & Yes & Yes & 47,248 \\
Observations & 47,248 & 47,248 & 47,248 & 47,248 & 47,248 & \\
F-test of excl. instrument & 111.07 & & & & &
\end{tabular}


Table 4. Small business lending and bank mergers at the county level by size of acquirer

This table reports the results of regressions estimating the determinants of small business lending at the county level. Small SBL are loans with amounts $<\$ 100 \mathrm{~K}$; Medium SBL are those between $\$ 100 \mathrm{~K}$ and $\$ 250 \mathrm{~K}$, and Large SBL are those between $\$ 250 \mathrm{~K}$ and $\$ 1 \mathrm{M}$. Loans to small firms are loans to firms with revenues $<\$ 1$ million. Our key explanatory variables are Merger intensitysmall acquirer (large acquirer) - the average share of county deposits of banks involved in mergers with a small (large) acquirer over the prior three years. Large (small) acquirers are those with assets $\geq \$ 10 \mathrm{~B}(<\$ 10 \mathrm{~B})$. Standard errors are clustered at the county and year level. $t$-statistics are reported in parentheses. All variables are defined in Appendix A. *** $(* *)\{*\}$ denotes significance at the $1 \%(5 \%)\{10 \%\}$ level.

\begin{tabular}{lccccc}
\hline \multicolumn{7}{c}{ Merger intensity by size of acquirers. } & & \\
\hline Dependent variable (Log): & SBL & Small SBL & Medium SBL & Large SBL & Loans to small firms \\
\hline Merger intensity-small acquirer [A] & $(1)$ & $(2)$ & $(3)$ & $(4)$ & $(5)$ \\
& $0.516^{* * *}$ & $0.378^{* * *}$ & $0.972^{* * *}$ & $0.806^{* *}$ & $0.738^{* * *}$ \\
Merger intensity-large acquirer [B] & $(6.08)$ & $(5.90)$ & $(4.62)$ & $(2.77)$ & $(6.31)$ \\
& $-0.265^{* *}$ & $-0.450^{* * *}$ & -0.287 & -0.090 & $-0.538^{* * *}$ \\
Controls & $(-2.11)$ & $(-3.63)$ & $(-1.18)$ & $(-0.30)$ & $(-3.50)$ \\
County fixed effects & Yes & Yes & Yes & Yes & Yes \\
Year fixed effects & Yes & Yes & Yes & Yes & Yes \\
Observations & Yes & Yes & Yes & Yes & Yes \\
Adjusted $\mathrm{R}^{2}$ & 47,248 & 47,248 & 47,248 & 47,248 & 47,248 \\
$F$-test [A=B] & 0.964 & 0.976 & 0.784 & 0.749 & 0.943 \\
& $27.08^{* * *}$ & $29.21^{* * *}$ & $15.54 * * *$ & $4.75^{* *}$ & $42.51^{* * *}$ \\
\hline
\end{tabular}


Table 5. Small business lending and bank mergers at the county level by acquirer size and location of acquirer.

This table reports the results of regressions estimating the determinants of small business lending at the county level. Small SBL are loans with amounts < $\$ 100 \mathrm{~K}$; Medium SBL are those between $\$ 100 \mathrm{~K}$ and $\$ 250 \mathrm{~K}$, and Large SBL are those between $\$ 250 \mathrm{~K}$ and $\$ 1 \mathrm{M}$. Loans to small firms are loans to firms with revenues < \$1 million. In Panel A we report results using: Merger intensity-instate (out-of-state)- the share of county deposits of banks involved in mergers with an in-state (out-of-state) acquirer, averaged over the prior three years. In Panel B we report results using merger intensity measures based on the distance between the target and the acquirer's county. Specifically, Long (short) distance is an indicator variable that equals one for mergers in which the distance between the acquirer's headquarter county and the target's county is above (below) the median distance in a given year. We use these indicators to construct Merger intensity-long (short) distance the share of county deposits of banks involved in mergers with acquirers from long (short) distances, averaged over the prior three years. In Panel $\mathrm{C}$ we show results using Merger intensity-instate presence (no in-state presence)- the share of county deposits of banks involved in mergers with an acquirer with (without) a physical presence (branch) in the target's state pre-merger, averaged over the prior three years. Controls (unreported to conserve space) include: Herfindahl-deposits; Log(bank assets); Loans-to-assets; RE loans-to-loans; C\&I loans-to-loans; Personal loans-toloans; Capital ratio; Nonperforming loans-to-loans; Ln(population), Ln(wages), Change in HPI (\%), and Employment growth. We construct the county-level bank characteristics as weighted averages across all banks in the county using the bank's proportion of local branches as weights. The last rows of each panel report the $F$-statistic for the test of equality of the coefficients on Merger intensity-in-state (short distance) and Merger intensity-out-of-state (long distance). Standard errors are clustered at the county and year level. $t$-statistics are reported in parentheses. All variables are defined in Appendix A. *** $(* *)\{*\}$ denotes significance at the $1 \%(5 \%)\{10 \%\}$ level.

\begin{tabular}{|c|c|c|c|c|c|}
\hline \multicolumn{6}{|c|}{ Panel A. Merger intensity by location of acquirer. In-state vs. out-of-state } \\
\hline Dependent variable (Log): & SBL & Small SBL & Medium SBL & Large SBL & Loans to small firms \\
\hline & $(1)$ & $(2)$ & (3) & (4) & $(5)$ \\
\hline \multirow{2}{*}{ Merger intensity in-state [A] } & $0.389 * * *$ & $0.242 * * *$ & $0.718 * * *$ & $0.570^{*}$ & $0.448 * * *$ \\
\hline & $(3.92)$ & $(3.27)$ & $(2.94)$ & $(1.65)$ & $(3.42)$ \\
\hline \multirow{2}{*}{ Merger intensity out-of-state [B] } & $0.135^{*}$ & -0.014 & $0.577 * * *$ & 0.306 & 0.063 \\
\hline & $(1.74)$ & $(-0.17)$ & $(3.40)$ & $(1.29)$ & $(0.52)$ \\
\hline Controls & Yes & Yes & Yes & Yes & Yes \\
\hline County fixed effects & Yes & Yes & Yes & Yes & Yes \\
\hline Year fixed effects & Yes & Yes & Yes & Yes & Yes \\
\hline Observations & 47,248 & 47,248 & 47,248 & 47,248 & 47,248 \\
\hline Adjusted $\mathrm{R}^{2}$ & 0.964 & 0.976 & 0.784 & 0.749 & 0.943 \\
\hline$F$-test $[\mathrm{A}=\mathrm{B}]$ & $4.94 * *$ & $6.90 * *$ & 0.28 & 0.41 & $6.51 * *$ \\
\hline
\end{tabular}

Panel B. Merger intensity by location of acquirer. By distance.

\begin{tabular}{lccccc}
\hline Dependent variable (Log): & SBL & Small SBL & Medium SBL & Large SBL & Loans to small firms \\
\hline Merger intensity short-distance [A] & $(1)$ & $(2)$ & $(3)$ & $(4)$ & $(5)$ \\
& $0.344^{* * *}$ & $0.195^{* *}$ & $0.626^{* * *}$ & $0.528^{* *}$ & $0.402^{* * *}$ \\
Merger intensity long distance [B] & $(3.61)$ & $(2.36)$ & $(2.96)$ & $(2.12)$ & $(3.02)$ \\
& $0.152^{*}$ & 0.004 & $0.653^{* * *}$ & 0.319 & 0.065 \\
Controls & $(1.75)$ & $(0.05)$ & $(3.49)$ & $(1.10)$ & $(0.51)$ \\
County fixed effects & Yes & Yes & Yes & Yes & Yes \\
Year fixed effects & Yes & Yes & Yes & Yes & Yes \\
Observations & Yes & Yes & Yes & Yes & Yes \\
Adjusted R & 47,248 & 47,248 & 47,248 & 47,248 & 47,248 \\
$F$-test [A=B] & 0.964 & 0.976 & 0.784 & 0.749 & 0.943 \\
& 2.60 & $3.10^{*}$ & 0.01 & 0.35 & $4.65^{* *}$ \\
\hline
\end{tabular}


Table 5. Small business lending and bank mergers at the county level by acquirer size and location of acquirer. Continued.

Panel C. Merger intensity by acquirer presence in target's state.

\begin{tabular}{lccccc}
\hline Dependent variable (Log): & SBL & Small SBL & Medium SBL & Large SBL & Loans to small firms \\
\hline Merger intensity in-state presence [A] & $(1)$ & $(2)$ & $(3)$ & $(4)$ & $(5)$ \\
& $0.368^{* * *}$ & $0.188^{* * *}$ & $0.687^{* * *}$ & $0.589^{* *}$ & $0.387^{* * * *}$ \\
Merger intensity no in-state presence [B] & $(4.44)$ & $(2.58)$ & $(3.37)$ & $(2.26)$ & $(3.38)$ \\
& 0.008 & -0.077 & $0.544^{* * *}$ & 0.092 & -0.072 \\
Controls & $(0.10)$ & $(-1.21)$ & $(3.00)$ & $(0.31)$ & $(-0.51)$ \\
County fixed effects & Yes & Yes & Yes & Yes & Yes \\
Year fixed effects & Yes & Yes & Yes & Yes & Yes \\
Observations & Yes & Yes & Yes & Yes & Yes \\
Adjusted R $\mathrm{R}^{2}$ & 47,248 & 47,248 & 47,248 & 47,248 & 47,248 \\
$F$-test [A=B] & 0.964 & 0.976 & 0.784 & 0.749 & 0.943 \\
& $12.29^{* * *}$ & $11.38^{* * *}$ & 0.33 & 1.69 & $8.70^{* * *}$ \\
\hline
\end{tabular}


Table 6. Small business lending and bank mergers at the county level by size and location of acquirer.

This table reports the results of regressions estimating the determinants of small business lending at the county level Small SBL are loans with amounts < \$100K; Medium SBL are those between $\$ 100 \mathrm{~K}$ and $\$ 250 \mathrm{~K}$, and Large SBL are those between $\$ 250 \mathrm{~K}$ and $\$ 1 \mathrm{M}$. Loans to small firms are loans to firms with revenues $<\$ 1$ million. Our key explanatory variables are merger intensity measures based on the size and location of the acquirer. Specifically, Merger intensity-small, in-state (out-of-state) is the share of county deposits of banks involved in mergers with a small, in-state (out-of-state) acquirer, averaged over the prior three years. Similarly, Merger intensity-large, in-state (out-of-state) is the share of county deposits of banks involved in mergers with a large, in-state (outof-state) acquirer, averaged over the prior three years. Large (small) acquirers are those with assets $\geq \$ 10 \mathrm{~B}(\angle \$ 10 \mathrm{~B})$ in assets. Controls (unreported to conserve space) include: Herfindahl-deposits; Log(bank assets); Loans-to-assets; RE loans-to-loans; C\&I loans-toloans; Personal loans-to-loans; Capital ratio; Nonperforming loans-to-loans; Ln(population), Ln(wages), Change in HPI (\%), and Employment growth. We construct the county-level bank characteristics as weighted averages across all banks in the county using the bank's proportion of local branches as weights. The last row reports the $F$-statistic for the test of equality of the coefficients on Merger intensity-small, in-state acquirer and Merger intensity-large, out-of-state acquirer. Standard errors are clustered at the county and year level. $t$-statistics are reported in parentheses. All variables are defined in Appendix A. *** $(* *)\{*\}$ denotes significance at the $1 \%(5 \%)\{10 \%\}$ level.

\begin{tabular}{|c|c|c|c|c|c|}
\hline \multicolumn{6}{|c|}{ Merger intensity by size and location of acquirer. } \\
\hline \multirow[t]{2}{*}{ Dependent variable (Log): } & SBL & Small SBL & Medium SBL & Large SBL & Loans to small firms \\
\hline & $(1)$ & $(2)$ & $(3)$ & (4) & $(5)$ \\
\hline \multirow{2}{*}{ Merger intensity- small, in-state [A] } & $0.480 * * *$ & $0.362 * * *$ & $0.873 * * *$ & $0.673^{*}$ & $0.657 * * *$ \\
\hline & $(4.91)$ & $(5.00)$ & $(3.35)$ & $(1.94)$ & $(5.34)$ \\
\hline \multirow{2}{*}{ Merger intensity-large out-of-state [B] } & -0.099 & $-0.229 * *$ & 0.252 & -0.086 & $-0.362 * * *$ \\
\hline & $(-1.34)$ & $(-2.47)$ & $(1.34)$ & $(-0.30)$ & $(-3.19)$ \\
\hline \multirow{2}{*}{ Merger intensity- small, out-of-state [C] } & $0.575 * * *$ & $0.385 * * *$ & $1.183 * * *$ & $1.054 * *$ & $0.855^{* * *}$ \\
\hline & $(4.11)$ & $(3.56)$ & $(3.30)$ & $(2.54)$ & $(4.31)$ \\
\hline \multirow{2}{*}{ Merger intensity-large in-state [D] } & -0.022 & $-0.294^{*}$ & 0.019 & 0.087 & $-0.492 *$ \\
\hline & $(-0.11)$ & $(-1.85)$ & $(0.05)$ & $(0.16)$ & $(-1.67)$ \\
\hline Controls & Yes & Yes & Yes & Yes & Yes \\
\hline County fixed effects & Yes & Yes & Yes & Yes & Yes \\
\hline Year fixed effects & Yes & Yes & Yes & Yes & Yes \\
\hline Observations & 47,248 & 47,248 & 47,248 & 47,248 & 47,248 \\
\hline Adjusted $\mathrm{R}^{2}$ & 0.964 & 0.976 & 0.784 & 0.749 & 0.943 \\
\hline$F$-test $[\mathrm{A}=\mathrm{B}]$ & $17.63 * * *$ & $20.92 * * *$ & $4.05 *$ & 2.46 & $29.60 * * *$ \\
\hline$F$-test $[\mathrm{B}=\mathrm{D}]$ & 0.14 & 0.13 & 0.28 & 0.07 & 0.20 \\
\hline$F$-test $[\mathrm{A}=\mathrm{C}]$ & 0.35 & 0.04 & 0.49 & 0.61 & 0.91 \\
\hline
\end{tabular}


Table 7. Logit Regressions - Target Characteristics by acquirer size.

Table shows results from logistic regressions assessing the probability of the acquirer in a merger involving small target banks (assets $<\$ 10 M$ ) being: Small (large) or in-state (out-of-state). Large (small) acquirers are those with assets $\geq(<) \$ 10$ billion (in constant 2010 US\$ billion). Controls include various merger and target characteristics measured as of $t$-1: Relative size- the Log(acquirer asses/target assets); Core-deposits-to-assets; SB loans-to-assets; Loans-to-assets; ROA- net income plus interest expense scaled by total assets; Equity-to-assets; Noninterest income-to-income; Noninterest expense-to-assets, and Nonperforming loans-to-total loans. Data on bank mergers were obtained from the FDIC Report of Changes. We exclude deals that involve government assistance and those with missing financial data on targets or acquirers from the Call Reports. Our sample consists of 4,552 mergers involving small target banks. All variables are defined in Appendix A. $* * *(* *)\{*\}$ denotes significance at the $1 \%(5 \%)\{10 \%\}$ level.

\begin{tabular}{|c|c|c|c|c|c|c|}
\hline \multirow[t]{2}{*}{ Dependent Variable: } & \multicolumn{3}{|c|}{ Pr.(small acquirer) } & \multicolumn{3}{|c|}{ Pr. (In-state) } \\
\hline & (1) & (2) & (3) & (4) & (5) & (6) \\
\hline Core deposits-to-assets & $\begin{array}{c}0.092 * * * \\
(13.26)\end{array}$ & $\begin{array}{c}0.096 * * * \\
(14.10)\end{array}$ & $\begin{array}{c}0.102 * * * \\
(14.00)\end{array}$ & $\begin{array}{c}0.025 * * * \\
(7.34)\end{array}$ & $\begin{array}{c}0.024 * * * \\
(6.42)\end{array}$ & $\begin{array}{c}0.023 * * * \\
(6.23)\end{array}$ \\
\hline SB Loans $\%$ assets & $\begin{array}{c}0.048 * * * \\
(6.36)\end{array}$ & $\begin{array}{c}0.046 * * * \\
(5.64)\end{array}$ & $\begin{array}{c}0.055^{* * * *} \\
(5.87)\end{array}$ & $\begin{array}{c}0.012 * * * \\
(2.74)\end{array}$ & $\begin{array}{c}0.009 * * \\
(2.14)\end{array}$ & $\begin{array}{c}0.012 * * \\
(2.57)\end{array}$ \\
\hline Loans-to-assets & $\begin{array}{c}-0.022 * * * \\
(-4.29)\end{array}$ & $\begin{array}{c}-0.020 * * * \\
(-3.96)\end{array}$ & $\begin{array}{c}-0.015 * * * \\
(-2.80)\end{array}$ & $\begin{array}{c}-0.009 * * * \\
(-3.08)\end{array}$ & $\begin{array}{c}-0.012 * * * \\
(-3.87)\end{array}$ & $\begin{array}{c}-0.012 * * * \\
(-3.66)\end{array}$ \\
\hline ROA & & $\begin{array}{c}-0.259 * * * \\
(-2.95)\end{array}$ & $\begin{array}{c}-0.216 * * * \\
(-2.59)\end{array}$ & & $\begin{array}{l}0.015 \\
(0.35)\end{array}$ & $\begin{array}{l}-0.016 \\
(-0.33)\end{array}$ \\
\hline Equity-to-assets & & $\begin{array}{c}0.061 * * * \\
(3.08)\end{array}$ & $\begin{array}{c}0.039 * * \\
(1.97)\end{array}$ & & $\begin{array}{l}0.012 \\
(1.07)\end{array}$ & $\begin{array}{l}0.001 \\
(0.10)\end{array}$ \\
\hline Non-int. income-to-income & & $\begin{array}{c}-0.034 * * * \\
(-4.36)\end{array}$ & $\begin{array}{c}-0.026^{* * *} \\
(-3.41)\end{array}$ & & $\begin{array}{c}-0.023 * * * \\
(-6.23)\end{array}$ & $\begin{array}{c}-0.022 * * * \\
(-5.51)\end{array}$ \\
\hline Non-int. exp.-to-assets & & $\begin{array}{c}0.498 * * * \\
(6.14)\end{array}$ & $\begin{array}{c}0.427 * * * \\
(5.19)\end{array}$ & & $\begin{array}{c}0.104 * * * \\
(2.73)\end{array}$ & $\begin{array}{c}0.102 * * \\
(2.51)\end{array}$ \\
\hline NPL-to-loans & & & $\begin{array}{l}-1.075 \\
(-0.18)\end{array}$ & & & $\begin{array}{c}-6.333 * * \\
(-2.01)\end{array}$ \\
\hline Relative size & $\begin{array}{c}-1.560 * * * \\
(-17.48)\end{array}$ & $\begin{array}{c}-1.701 * * * \\
(-17.88)\end{array}$ & $\begin{array}{c}-1.776 * * * \\
(-19.35)\end{array}$ & $\begin{array}{c}-0.517 * * * \\
(-9.07)\end{array}$ & $\begin{array}{c}-0.527 * * * \\
(-8.88)\end{array}$ & $\begin{array}{c}-0.519 * * * \\
(-8.38)\end{array}$ \\
\hline Constant & $\begin{array}{c}2.609 * * * \\
(3.68)\end{array}$ & $\begin{array}{c}2.521 * * * \\
(2.90)\end{array}$ & $\begin{array}{l}0.620 \\
(0.70)\end{array}$ & $\begin{array}{c}1.431 * * * \\
(3.70)\end{array}$ & $\begin{array}{c}1.779 * * * \\
(3.91)\end{array}$ & $\begin{array}{c}1.189 * * \\
(2.25)\end{array}$ \\
\hline Observations & 4,552 & 4,544 & 4,102 & 4,552 & 4,544 & 4,102 \\
\hline Year fixed effects & Yes & Yes & Yes & Yes & Yes & Yes \\
\hline Bank fixed effects & No & No & No & No & No & No \\
\hline Pseudo $\mathrm{R}^{2}$ & 0.537 & 0.566 & 0.588 & 0.107 & 0.117 & 0.115 \\
\hline
\end{tabular}


Table 8 . Small business lending and bank mergers at the county level by county opacity by size and location of acquirer.

This table reports the results of regressions estimating the determinants of small business lending at the county level. Small SBL are loans < \$100K; Medium SBL are those between \$100K and \$250K, and Large SBL are those between \$250K and \$1M. Loans to small firms are loans to firms with revenues $<\$ 1$ million. Merger intensity is the share of county deposits of target banks involved in mergers, averaged over the prior three years. We interact the merger variables with Opaque county-calculated annually as indicator that equals one if the fraction of employment by small firms (those with fewer than 50 employees) in the county is in the top tercile of the distribution and zero otherwise. Large (small) acquirers are those with assets $\geq \$ 10 \mathrm{~B}(<\$ 10 \mathrm{~B})$ in assets. Panel B presents results using Merger intensity-in-state (out-of-state)-the weighted average share of county deposits in banks involved in mergers with in-state (out-of-state) acquirers over the prior three years. All variables are defined in Appendix A. The last rows report $F$-statistics from tests of significance of the sum of the coefficients Merger intensity x Opaque county + Merger intensity. Standard errors are clustered at the county and year level. $t$-statistics are reported in parentheses. $* * *(* *)\{*\}$ denotes significance at the $1 \%(5 \%)\{10 \%\}$ level.

\begin{tabular}{|c|c|c|c|c|c|}
\hline \multicolumn{6}{|c|}{ County Opacity } \\
\hline Dependent variable (Log): & SBL & Small SBL & Medium SBL & Large SBL & Loans to small firms \\
\hline & $(1)$ & $(2)$ & $(3)$ & (4) & $(5)$ \\
\hline Merger intensity x Opaque county [A] & $\begin{array}{c}0.173 * * \\
(2.22)\end{array}$ & $\begin{array}{l}0.096 \\
(1.25)\end{array}$ & $\begin{array}{l}0.139 \\
(0.51)\end{array}$ & $\begin{array}{c}0.673 * * \\
(2.37)\end{array}$ & $\begin{array}{c}0.257 * * \\
(2.20)\end{array}$ \\
\hline Merger intensity [B] & $\begin{array}{c}0.177 * * \\
(2.11)\end{array}$ & $\begin{array}{l}0.067 \\
(0.85)\end{array}$ & $\begin{array}{c}0.586^{* * * *} \\
(3.27)\end{array}$ & $\begin{array}{l}0.110 \\
(0.61)\end{array}$ & $\begin{array}{l}0.129 \\
(1.00)\end{array}$ \\
\hline Opaque county & $\begin{array}{l}0.022 \\
(1.59)\end{array}$ & $\begin{array}{l}0.009 \\
(0.80)\end{array}$ & $\begin{array}{l}-0.013 \\
(-0.32)\end{array}$ & $\begin{array}{l}0.066 \\
(1.42)\end{array}$ & $\begin{array}{l}0.021 \\
(1.31)\end{array}$ \\
\hline Controls & Yes & Yes & Yes & Yes & Yes \\
\hline Year fixed effects & Yes & Yes & Yes & Yes & Yes \\
\hline Observations & 46,615 & 46,615 & 46,615 & 46,615 & 46,615 \\
\hline Adjusted $\mathrm{R}^{2}$ & 0.964 & 0.976 & 0.783 & 0.748 & 0.943 \\
\hline F-test: $[\mathrm{A}+\mathrm{B}]=0$ & $25.68 * * *$ & $7.40 * *$ & $9.74 * * *$ & $6.73 * *$ & $14.29 * * *$ \\
\hline
\end{tabular}


Table 9. Bank-Level Results. SBL originations around merger.

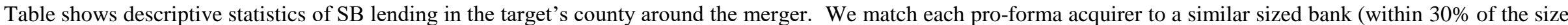

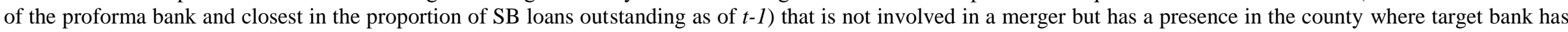

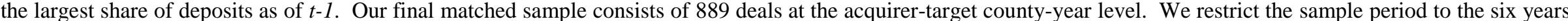

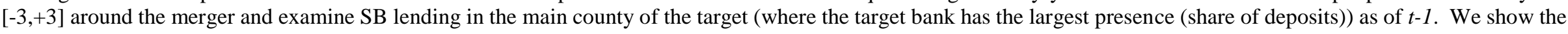

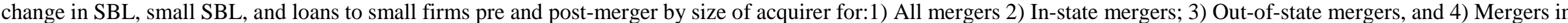

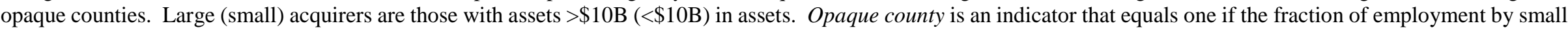

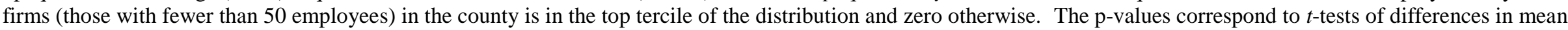
between changes in lending by large and small acquirers. $* * *(* *)\{*\}$ denotes significance at the $1 \%(5 \%)\{10 \%\}$ level.

\begin{tabular}{|c|c|c|c|c|c|}
\hline All mergers: & Small acquirers & Large acquirer & Difference & $\mathrm{p}$-value & Obs. \\
\hline$\Delta \log (\mathrm{SB}$ loans $)$ & 0.766 & 0.186 & $0.580^{* * * *}$ & 0.000 & 889 \\
\hline$\Delta \log ($ small SB loans $)$ & 0.814 & 0.273 & $0.541 * * *$ & 0.000 & 889 \\
\hline$\Delta \log$ (Loans to small firms) & 0.803 & 0.231 & $0.572 * * *$ & 0.000 & 889 \\
\hline In-state mergers: & Small acquirers & Large acquirer & Difference & p-value & Obs. \\
\hline$\Delta \log (\mathrm{SB}$ loans $)$ & 0.734 & 0.020 & $0.714 * * *$ & 0.000 & 549 \\
\hline$\Delta \log ($ small SB loans $)$ & 0.797 & 0.007 & $0.791 * * *$ & 0.000 & 549 \\
\hline$\Delta \log$ (Loans to small firms) & 0.778 & -0.091 & $0.869 * * *$ & 0.000 & 549 \\
\hline Out-of-state mergers: & Small acquirers & Large acquirer & Difference & $\mathrm{p}$-value & Obs. \\
\hline$\Delta \log ($ SB loans $)$ & 0.864 & 0.249 & $0.615^{* * *}$ & 0.000 & 340 \\
\hline$\Delta \log ($ small SB loans $)$ & 0.864 & 0.374 & $0.490 * *$ & 0.013 & 340 \\
\hline$\Delta \log$ (Loans to small firms) & 0.878 & 0.353 & $0.524 * *$ & 0.015 & 340 \\
\hline Mergers in opaque counties: & Small acquirers & Large acquirer & Difference & p-value & Obs. \\
\hline$\Delta \log (\mathrm{SB}$ loans $)$ & 1.464 & 0.320 & $1.145^{*}$ & 0.084 & 80 \\
\hline$\Delta \log ($ small SB loans) & 1.421 & -0.040 & $1.461 * *$ & 0.038 & 80 \\
\hline$\Delta \log$ (Loans to small firms) & 1.619 & 0.040 & $1.579 *$ & 0.051 & 80 \\
\hline
\end{tabular}


Table 10. Bank-Level Results. SBL originations around merger.

Table shows results from matched sample regressions of SB lending in the target's county around the merger. We match each proforma acquirer to a similar sized bank (within 30\% of the size of the proforma bank and closest in the proportion of SB loans outstanding as of $t-1$ ) that is not involved in a merger but has a presence in the county where target bank has the largest share of deposits as of $t-1$. Our final matched sample consists of 693 deals at the acquirer-target county-year level. Treat is an indicator equal to one for the proforma acquirers and zero for the control bank. Post is an indicator equal to one starting the year after the merger and zero otherwise. We restrict the sample period to the six years $[-3,+3]$ around the merger and examine SB lending in the main county of the target (where the target bank has the largest presence (share of deposits)) as of $t-1$. Panel A (B) shows results from difference-in-differences regressions using the sample of small (large) acquirers. Large (small) acquirers are those with assets $>\$ 10 \mathrm{~B}(\angle \$ 10 \mathrm{~B})$ in assets. Bank level controls (lagged) include: Size; Capital ratio; NPL ratio; RE loans \%; C\&I loans \%; Personal loans \%, and Loans-to-assets. We do not report the control variables in Panel B to conserve space. County-level controls include: Herfindahl-deposits; Employment growth; Ln(Population); Change in HPI and Ln(wage). County and year fixed effects are included in all regressions. The last rows report $F$-statistics from tests of significance of the sum of the coefficients Post x Treat + Treat. We cluster standard errors at the county and year level. Robust $t$-statistics are reported in parentheses. $* * *(* *)\{*\}$ denotes significance at the $1 \%(5 \%)\{10 \%\}$ level.

\begin{tabular}{|c|c|c|c|c|c|}
\hline \multicolumn{6}{|c|}{ Panel A. Post-Merger SB lending in target county by Small acquirers. } \\
\hline Dependent variable $(\log )$ : & SBL & Small SBL & Medium SBL & Large SBL & Loans to small firms \\
\hline & $(1)$ & $(2)$ & (3) & (4) & $(5)$ \\
\hline Post $\mathrm{x}$ Treat & $\begin{array}{c}0.606 * * * \\
(7.09)\end{array}$ & $\begin{array}{c}0.751 * * * \\
(5.40)\end{array}$ & $\begin{array}{c}0.822 * * * \\
(5.84)\end{array}$ & $\begin{array}{c}0.756 * * * \\
(5.00)\end{array}$ & $\begin{array}{c}0.428^{* *} \\
(2.11)\end{array}$ \\
\hline Post & $\begin{array}{c}-0.171^{* *} \\
(-2.51)\end{array}$ & $\begin{array}{c}-0.268 * * * \\
(-3.54)\end{array}$ & $\begin{array}{l}-0.080 \\
(-0.63)\end{array}$ & $\begin{array}{c}-0.172^{* *} \\
(-2.14)\end{array}$ & $\begin{array}{l}0.091 \\
(0.78)\end{array}$ \\
\hline Treat & $\begin{array}{c}2.175 * * * \\
(15.42)\end{array}$ & $\begin{array}{c}2.422 * * * \\
(14.08)\end{array}$ & $\begin{array}{c}3.160 * * * \\
(13.86)\end{array}$ & $\begin{array}{c}3.355 * * * \\
(13.97)\end{array}$ & $\begin{array}{c}2.772 * * * * \\
(12.34)\end{array}$ \\
\hline Ln (assets) & $\begin{array}{l}0.113 \\
(1.68)\end{array}$ & $\begin{array}{l}-0.055 \\
(-0.60)\end{array}$ & $\begin{array}{l}0.063 \\
(0.60)\end{array}$ & $\begin{array}{c}0.255^{*} \\
(2.09)\end{array}$ & $\begin{array}{l}0.008 \\
(0.08)\end{array}$ \\
\hline Equity-to-assets t-1 & $\begin{array}{l}0.564 \\
(0.87)\end{array}$ & $\begin{array}{l}1.558^{*} \\
(1.77)\end{array}$ & $\begin{array}{l}-3.238^{*} \\
(-1.91)\end{array}$ & $\begin{array}{l}-3.296^{*} \\
(-1.95)\end{array}$ & $\begin{array}{l}1.512 \\
(0.94)\end{array}$ \\
\hline NPL ratio t-1 & $\begin{array}{l}-0.945 \\
(-0.39)\end{array}$ & $\begin{array}{l}-4.985 \\
(-1.19)\end{array}$ & $\begin{array}{c}-8.284^{*} \\
(-2.08)\end{array}$ & $\begin{array}{l}-4.292 \\
(-1.04)\end{array}$ & $\begin{array}{l}0.970 \\
(0.14)\end{array}$ \\
\hline RE loans \% t-1 & $\begin{array}{l}1.501 * \\
(2.07)\end{array}$ & $\begin{array}{c}-1.453 * * \\
(-2.20)\end{array}$ & $\begin{array}{c}3.096 * * * \\
(3.16)\end{array}$ & $\begin{array}{c}4.558 * * * \\
(4.79)\end{array}$ & $\begin{array}{c}6.998 * * * * \\
(14.70)\end{array}$ \\
\hline C\&I loans \% $\mathrm{t}-1$ & $\begin{array}{c}1.729 * * \\
(2.18)\end{array}$ & $\begin{array}{l}0.675 \\
(0.83)\end{array}$ & $\begin{array}{l}-0.832 \\
(-0.82)\end{array}$ & $\begin{array}{l}0.023 \\
(0.02)\end{array}$ & $\begin{array}{c}3.986 * * * \\
(3.87)\end{array}$ \\
\hline Personal loans $\% \mathrm{t}-1$ & $\begin{array}{l}-0.345 \\
(-0.34)\end{array}$ & $\begin{array}{l}-0.534 \\
(-0.57)\end{array}$ & $\begin{array}{l}-0.274 \\
(-0.23)\end{array}$ & $\begin{array}{l}-1.056 \\
(-0.79)\end{array}$ & $\begin{array}{c}3.200^{* * *} \\
(2.20)\end{array}$ \\
\hline Loans-to-assets t-1 & $\begin{array}{l}0.014 \\
(0.03)\end{array}$ & $\begin{array}{l}0.610 \\
(0.94)\end{array}$ & $\begin{array}{l}1.012 \\
(1.48)\end{array}$ & $\begin{array}{l}-0.100 \\
(-0.13)\end{array}$ & $\begin{array}{l}0.443 \\
(0.61)\end{array}$ \\
\hline Employment growth t-1 & $\begin{array}{l}1.439 \\
(1.25)\end{array}$ & $\begin{array}{l}0.099 \\
(0.09)\end{array}$ & $\begin{array}{l}2.007 \\
(1.09)\end{array}$ & $\begin{array}{l}2.290 \\
(1.52)\end{array}$ & $\begin{array}{l}6.745 \\
(1.55)\end{array}$ \\
\hline Ln (population) t-1 & $\begin{array}{l}2.467 * \\
(1.77)\end{array}$ & $\begin{array}{l}1.996 \\
(1.20)\end{array}$ & $\begin{array}{l}3.191 \\
(1.47)\end{array}$ & $\begin{array}{l}2.859 \\
(1.47)\end{array}$ & $\begin{array}{l}1.951 \\
(0.89)\end{array}$ \\
\hline $\operatorname{Ln}($ wage $) \mathrm{t}-1$ & $\begin{array}{l}-0.173 \\
(-0.39)\end{array}$ & $\begin{array}{l}0.435 \\
(0.92)\end{array}$ & $\begin{array}{l}-0.415 \\
(-0.53)\end{array}$ & $\begin{array}{l}-0.275 \\
(-0.38)\end{array}$ & $\begin{array}{l}0.506 \\
(0.37)\end{array}$ \\
\hline Change in HPI $t-1$ & $\begin{array}{c}0.018 * * * \\
(3.20)\end{array}$ & $\begin{array}{l}0.011 * \\
(2.00)\end{array}$ & $\begin{array}{c}0.016^{* *} \\
(2.41)\end{array}$ & $\begin{array}{l}0.012 \\
(1.28)\end{array}$ & $\begin{array}{c}0.027 * * \\
(2.39)\end{array}$ \\
\hline County fixed effects & Yes & Yes & Yes & Yes & Yes \\
\hline Year fixed effects & Yes & Yes & Yes & Yes & Yes \\
\hline Observations & 5,259 & 5,259 & 5,259 & 5,259 & 5,259 \\
\hline Adjusted $\mathrm{R}^{2}$ & 0.550 & 0.431 & 0.576 & 0.609 & 0.540 \\
\hline
\end{tabular}


Table 10. Bank-Level Results. SBL originations around merger. Continued.

Panel B. Post-Merger SB lending in target county by Large acquirers.

\begin{tabular}{lccccc}
\hline Dependent variable $(\mathrm{Log}):$ & SBL & Small SBL & Medium SBL & Large SBL & \multicolumn{2}{c}{ Loans to small firms } \\
\hline Post x Treat & $(1)$ & $(2)$ & $(3)$ & $(4)$ & $(5)$ \\
& 0.107 & -0.098 & -0.033 & 0.133 & 0.372 \\
Post & $(0.33)$ & $(-0.26)$ & $(-0.07)$ & $(0.51)$ & $(1.28)$ \\
& -0.222 & -0.099 & 0.144 & -0.137 & -0.292 \\
Treat & $(-0.90)$ & $(-0.47)$ & $(0.47)$ & $(-0.62)$ & $(-1.46)$ \\
& $2.411^{* * *}$ & $2.824 * * *$ & $3.606^{* * *}$ & $3.613 * * *$ & $3.165^{* * *}$ \\
Controls & $(8.38)$ & $(8.33)$ & $(8.96)$ & $(8.32)$ & $(8.38)$ \\
County fixed effects & Yes & Yes & Yes & Yes & Yes \\
Year fixed effects & Yes & Yes & Yes & Yes & Yes \\
Observations & Yes & Yes & Yes & Yes & Yes \\
Adjusted R & 2,148 & 2,148 & 2,148 & 2,148 & 2,148 \\
\hline
\end{tabular}


Figure 1. CRA Banks. Figure shows the number and average (median) asset size (in constant 2019 US \$ million) of banks that file the FFIEC's CRA Disclosure Reports. The FFIEC collects data on lending from regulatory reports filed by institutions in accordance with the requirements of the CRA. Specifically, all state member banks, state nonmember banks, national banks, and savings associations with assets in excess of an annually established threshold (roughly $\$ 1$ billion in constant 2005 dollars) for both of the prior two calendar years are subject to the data collection and reporting requirements of the CRA.

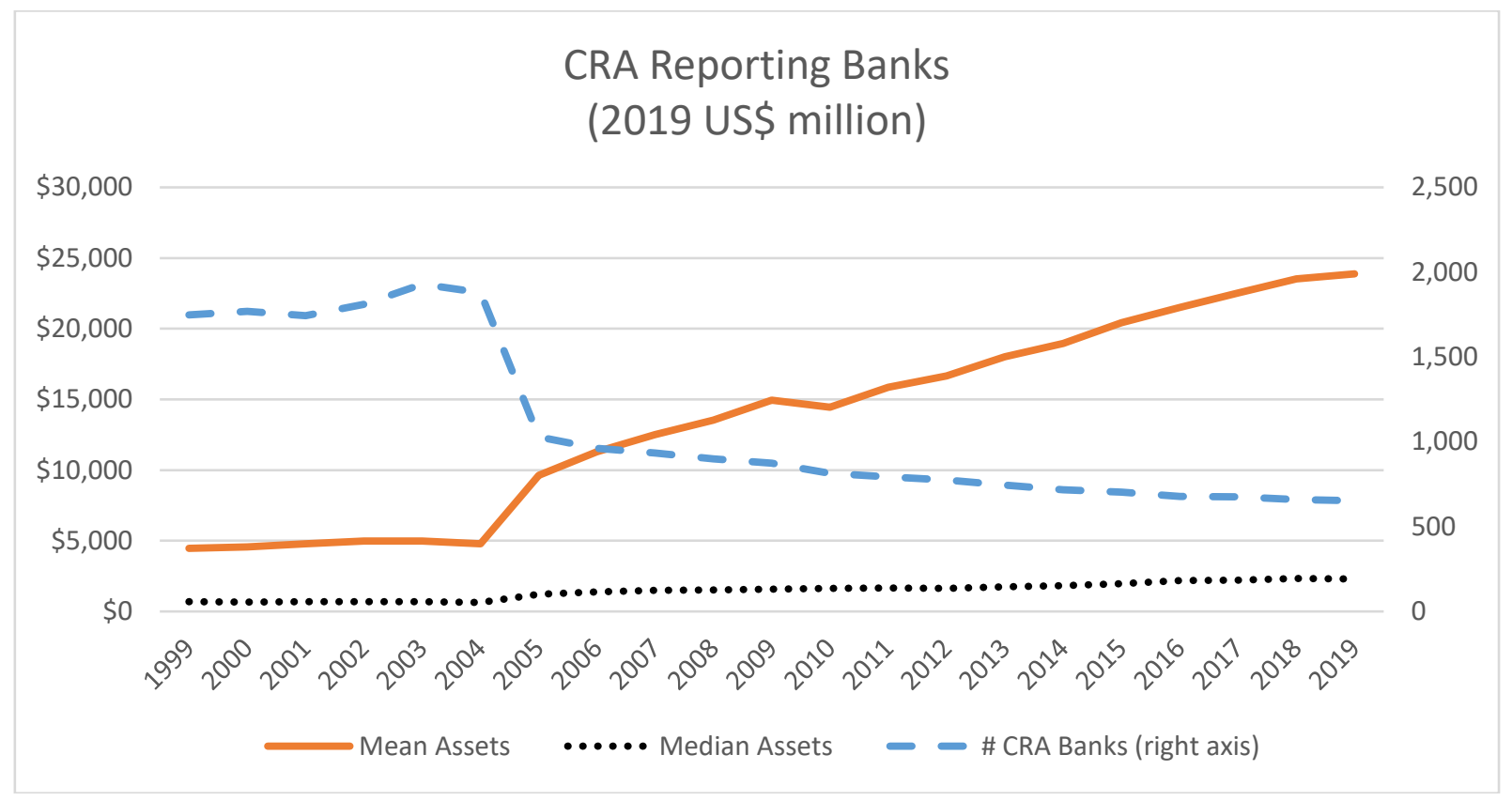


Figure 2. Bank Merger Activity by State.

Figure shows the distribution of the number of bank mergers by state. Bank mergers refer to all mergers involving acquirers with assets > \$100 million (in constant 2019 US \$s). Merger data are obtained from the FDIC's Report of Changes.

\section{\# of Bank Mergers by State.}

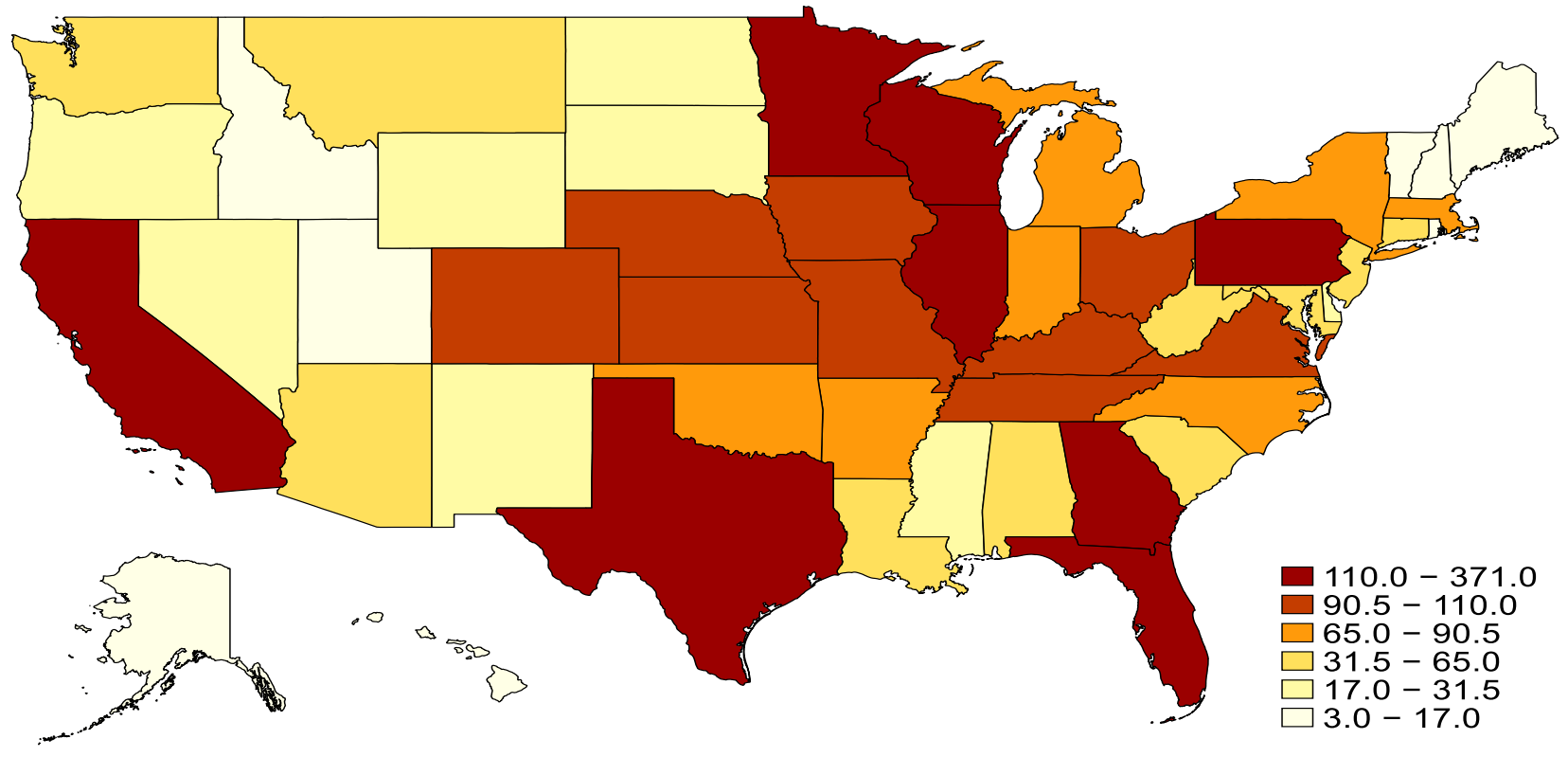


Appendix A. Variable Definitions

Variable name

Definition

Capital Ratio

The average equity-to-assets ratio of all banks in a county. We compute the average ratio as the sum of a bank's equity-to-assets ratio multiplied by the bank's proportion of local branches.

Change in HPI (\%)

CI loans-to-loans

Annual change in the Housing price index from the Federal Housing Finance Agency.

The average ratio of commercial and industrial (C\&I) loans-to-total loans of all banks in county. We compute the average ratio as the sum of a bank's CI loans-to-loan-to-assets ratio multiplied by the bank's proportion of local branches.

Employment growth

Annual growth in employment in the county. Source: Bureau of Economic Analysis

Herfindahl- deposits

Herfindahl index (HFI) using shares of total deposits by banks in a county. $H F I=\sum_{i=1}^{N}\left[\frac{D E P_{i, t}}{T O T_{c, t}}\right]^{2}$ DEP- total deposits by bank $i$ in county $c$.

TOT- total deposits in county $c$.

Large SBL

Ln (Population)

$\operatorname{Ln}($ wages $)$

Loans-to-assets

Loans to small firms

$\log$ (bank assets)

Total amount of small business loan originations between $\$ 250 \mathrm{~K}$ and $\$ 1$ million (constant 2016 US\$ 000s). Source: CRA Disclosure files.

The natural log of the total population in the county. Source: Bureau of Economic Analysis.

The natural log of the average real wages (wages and salaries divided by total wage and salary employment) in the county. Source: Bureau of Economic Analysis.

The average ratio of total loans-to-total assets of all banks in the county. We compute the average ratio as the sum of a bank's loans-to-assets ratio multiplied by the bank's proportion of local branches.

Total amount of small business loan originations to firms with revenues < \$1 million. Source: CRA Disclosure files.

The average size (log (book value of assets)) of all banks in the county. We compute the average as the sum of a bank's $\log$ (assets) multiplied by the bank's proportion of local branches.

Medium SBL

Merger intensity

Total amount of small business loan originations between $\$ 100 \mathrm{~K}-\$ 250 \mathrm{~K}$ (constant 2016 US\$ 000s). Source: CRA Disclosure files.

The share of deposits in the county held by target banks involved in a merger. The measure is averaged over the prior three years. Source: FDIC Report of Changes, and Summary of Deposits databases.

Merger intensity in-state (outof-state)

The share of deposits in county held by target banks involved in a merger with an in-state (out-of-state) acquirer, averaged over the prior three years. Source: FDIC Report of Changes, and Summary of Deposits databases.

Merger intensity large (small) acquirer

The share of deposits in county held by target banks involved in a merger with a large, $>\$ 10 \mathrm{~B}$ (small, $<=\$ 10 \mathrm{~B}$ ) acquirer, averaged over the prior three years. Source: FDIC Report of Changes, and Summary of Deposits databases. 
Appendix A. Variable Definitions. Continued.

\begin{tabular}{|c|c|}
\hline Variable name & Definition \\
\hline $\begin{array}{l}\text { Merger intensity-long (short) } \\
\text { distance }\end{array}$ & $\begin{array}{l}\text { The share of deposits in county held by target banks involved in a merger } \\
\text { with a long (short) distance acquirer, averaged over the prior three years. } \\
\text { Long (short) distance mergers are those in which the distance between } \\
\text { the target's county and the acquirer's headquarter county is above } \\
\text { (below) the median in a given year. Weight is the proportion of each } \\
\text { bank's deposits in each county. Source: FDIC Report of Changes, and } \\
\text { Summary of Deposits databases; NBER county distance database. }\end{array}$ \\
\hline NPL ratio & $\begin{array}{l}\text { The average ratio of total nonperforming loans-to-total loans of all banks } \\
\text { in then county. We compute the average ratio as the sum of a bank's } \\
\text { NPL-to-loans ratio multiplied by the bank's proportion of local branches, } \\
\text { following Berger et al. (2017). }\end{array}$ \\
\hline Opaque county & $\begin{array}{l}\text { An indicator equal to one if the fraction of small ( }<50 \text { employees) firm } \\
\text { employment in the county is in the top tercile of the distribution and } \\
\text { zero otherwise. Source: Quarterly Workforce Indicators (US Census). }\end{array}$ \\
\hline Personal loans \% & $\begin{array}{l}\text { The average personal loans-to-total loans ratio for all banks in a county. } \\
\text { We compute the average ratio as the sum of a bank's personal loans-to- } \\
\text { loan-to-assets ratio multiplied by the bank's proportion of local } \\
\text { branches. }\end{array}$ \\
\hline Predicted deals si,t & $\begin{array}{l}\text { Predicted bank mergers for state } i \text { in year } t \text {, estimated from state-pair- } \\
\text { year regressions using the number of bank mergers involving acquirers } \\
\text { from state } j \text { and targets from state } i \text {. Predicted values are aggregated at } \\
\text { the target state-year level to obtain the total predicted bank mergers for } \\
\text { state } i \text { in year } t\end{array}$ \\
\hline RE loans \% & $\begin{array}{l}\text { The average ratio of total real estate loans-to-total loans of all banks in } \\
\text { the county. We compute the average ratio as the sum of a bank's RE } \\
\text { loans-to-loans ratio multiplied by the bank's proportion of local } \\
\text { branches. }\end{array}$ \\
\hline SBL & $\begin{array}{l}\text { Total amount of small business loan originations (constant } 2016 \text { US\$ } \\
\text { 000s). Source: CRA Disclosure files }\end{array}$ \\
\hline SB Loans \% & The fraction of SB loans outstanding based on the call report. \\
\hline Small SBL & $\begin{array}{l}\text { Total amount of small business loan originations }<\$ 100 \mathrm{~K} \text { (constant } \\
2016 \text { US\$ 000s). Source: CRA Disclosure files. }\end{array}$ \\
\hline
\end{tabular}




\section{Appendix B. Acquirer Matches.}

This table reports descriptive statistics of the sample of acquirers and their matches. We match each pro-forma acquirer to a similar sized bank (within 30\% of the size of the proforma bank and closest in the proportion of SB loans outstanding as of $t-1)$ that is not involved in a merger but has a presence in the county where target bank has the largest share of deposits as of $t-1$. All variables are defined in Appendix A. t-statistics are reported in parentheses. $* * *(* *)\{*\}$ denotes significance at the $1 \%(5 \%)\{10 \%\}$ significance level.

\begin{tabular}{lccccc}
\hline \multicolumn{5}{c}{ Differences between } & Acquirers and Matched Controls as of t-1 \\
\hline & Treat & Control & Difference & Obs. & \# of deals \\
\hline Size (log (assets) & 15.397 & 15.383 & -0.014 & 0.857 & 889 \\
Assets (\$ billion) & 38.621 & 36.559 & -2.062 & 0.818 & 889 \\
SB loans \% & 0.165 & 0.163 & -0.002 & 0.770 & 889 \\
Equity-to-assets & 0.102 & 0.137 & $0.035^{* * *}$ & 0.000 & 889 \\
Loans-to-assets & 0.685 & 0.717 & $0.032^{* * *}$ & 0.000 & 889 \\
RE loans \% & 0.688 & 0.491 & $-0.197^{* * *}$ & 0.000 & 889 \\
C\&I loans \% & 0.165 & 0.263 & $0.098^{* * *}$ & 0.000 & 889 \\
Personal loans \% & 0.072 & 0.122 & $0.049^{* * *}$ & 0.000 & 889 \\
NPL ratio & 0.010 & 0.009 & -0.000 & 0.637 & 858 \\
\hline
\end{tabular}

